\title{
O aparelho quadrihélice (Quad-helix) e suas variações
}

\author{
Mario Sergio Duarte*
}

\begin{abstract}
Resumo
O presente artigo objetivou mostrar a eficiência dos vários desenhos do aparelho quadrihélice, de Ricketts, na correção das desarmonias dentoalveolares. Devido às suas várias formas de confecção, assim como de sua ativação, o quadrihélice tornou-se um acessório útil não somente na sobrecorreção da discrepância transversal e sagital, mas também no tratamento das más oclusões da Classe II, divisão 1, de Angle, principalmente nos casos em que a rotação do molar é desejada como parte do tratamento. Também é relevante o seu efeito no tratamento das mordidas abertas anteriores, atuando como coadjuvante no tratamento dos fatores ambientais que contribuem, muitas vezes, para exacerbar o desenvolvimento das más oclusões. Em relação ao alinhamento do arco dentário, o quadrihélice abrevia essa fase do tratamento em 4 a 5 meses (o tratamento convencional levaria muito mais tempo e pelo menos uma grande série de troca de arcos em mecânicas de nivelamento). Portanto, este trabalho tem a intenção de mostrar algumas das ativações possíveis do aparelho quadrihélice, bem como algumas de suas variações, que contribuem para conseguir resultados estáveis em longo prazo.
\end{abstract}

Palavras-chave: Quadrihélice. Expansão. Técnica Bioprogressiva.

\section{INTRODUÇÃO}

Juntamente com o arco utilidade e as mecânicas seccionais ${ }^{14,18}$, o aparelho quadrihélice tornouse parte integrante da técnica bioprogressiva ${ }^{3}$, pois confere rapidamente uma forma harmoniosa ao arco superior, a qual repercute no arco inferior. O aparelho quadrihélice foi introduzido por Ricketts em $1975^{2}$, e é uma modificação do aparelho "W", de Porter. Foi usado, inicialmente, com grande sucesso, pelo autor, no tratamento precoce dos pacientes fissurados com deficiências unilaterais ou bilaterais. A expansão ocorre desde que a força aplicada no complexo dentoalveolar seja superior aos limites do movimento transversal ortodôntico, ou seja, a partir de 3 newtons para uma criança. $\mathrm{O}$ aparelho comprime os ligamentos periodontais, desloca os processos alveolares, inclina os dentes de ancoragem e abre gradualmente a sutura mesopalatina ${ }^{13}$. A grande modificação criada por Ricketts no aparelho de Porter foi a confecção de quatro loops helicoidais, os quais acrescentaram um adicional de fio que varia de 40 a $50 \mathrm{~mm}$. Tal modificação teve o propósito de suavizar a magnitude de força e promover, desse modo, uma ação mais contínua (devido ao maior alcance de ativação pelo fato de o fio ser mais longo), bem como uma série de outras modificações, que serão descritas neste artigo. Ele é fabricado com fio elgiloy azul .040", da Rocky Mountain Orthodontics (EUA) e, para maior conforto do profissional ou técnico de laboratório, dever ser confeccionado com o alicate 065 da marca Orthopli (EUA).

* Especialista e Mestre em Ortodontia. Professor Pesquisador do Programa de Mestrado e Coordenador do Curso de Especialização em Ortodontia do CPO São Leopoldo Mandic, Campinas, SP. Doutorando em Ortodontia pelo CPO São Leopoldo Mandic. 
O quadrihélice deve ser soldado nas bandas dos primeiros molares superiores (embora alguns clínicos o utilizem encaixado nos tubos palatinos das bandas dos molares superiores), devendo os seus braços, que se localizam na região do palato, atingirem os caninos decíduos ou permanentes. Os dois loops helicoidais posteriores devem ser bem adaptados ao palato para não agredirem a língua e tão pouco o músculo palato-faríngeo; além disso, o seu segmento anterior deve ser contornado - não confeccioná-lo reto - assentando sobre a primeira rugosidade do palato; assim como as ativações devem ser feitas no segmento lateral e não no segmento anterior do aparelho, para não interferir no posicionamento da língua. Após o descruzamento da mordida cruzada, dependendo da severidade do caso (fatores etiológicos e idade cronológica do paciente), recomenda-se deixar o braço lateral do quadrihélice em contato com a superfície palatina dos dentes látero-posteriores durante a fase de nivelamento e alinhamento do arco dentário.

Dentro da filosofia bioprogressiva de Ricketts, o quadrihélice é um dispositivo usado principalmente para "destravar" as más oclusões e estabelecer função normal, assim como reconstruir uma forma de arco adequada por meio da expan- são dentoalveolar. Devido às suas variadas formas de desenho e ativações, o quadrihélice tornou-se um acessório útil no tratamento das más oclusões da Classe II, divisão 1, de Angle, pois a maioria dos pacientes acometidos por essa má oclusão apresenta o arco superior em forma de "V"2,6. Quando os dentes anteriores (superiores e inferiores) dos modelos de estudo são colocados numa relação de borda incisal, torna-se visível a necessidade de expansão dos segmentos láteroposteriores. Essa necessidade de expansão é ainda mais relevante quando os pacientes apresentam o palato ogival, relacionado à síndrome obstrutiva respiratória, nos quais é aplicada uma biomecânica semelhante àquela aplicada aos pacientes portadores de mordida cruzada posterior. Outro fator significante é sua competência em promover a rotação e a distalização dos molares superiores no tratamento das más oclusões da Classe II de Angle.

A expansão dos processos alveolares deverá ser empregada somente depois de correlatadas as medidas tomadas a partir dos modelos de estudo com aquelas obtidas por meio da telerradiografia cefalométrica póstero-anterior (PA). Torna-se impossível aplicar um diagnóstico apurado, bem
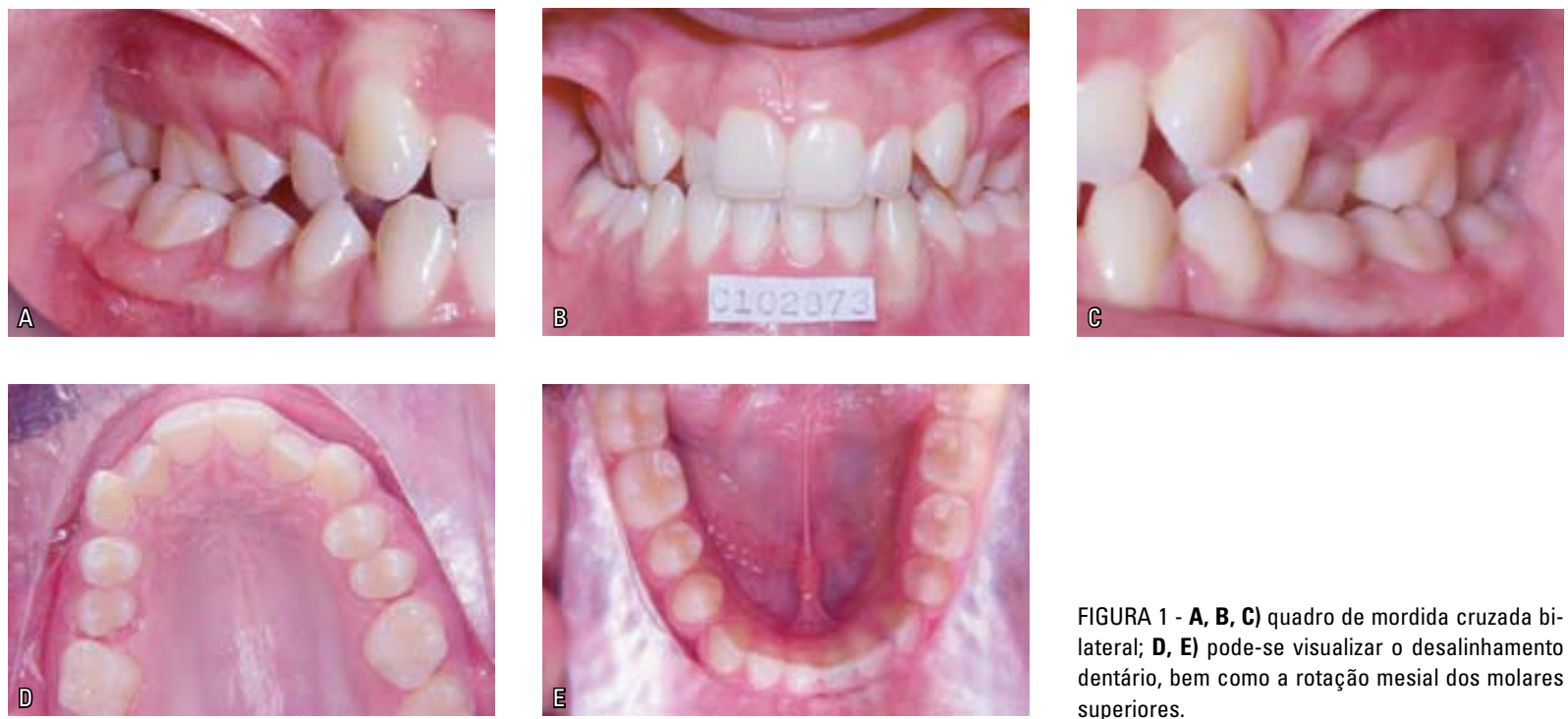

FIGURA 1 - A, B, C) quadro de mordida cruzada bilateral; D, E) pode-se visualizar o desalinhamento dentário, bem como a rotação mesial dos molares superiores. 

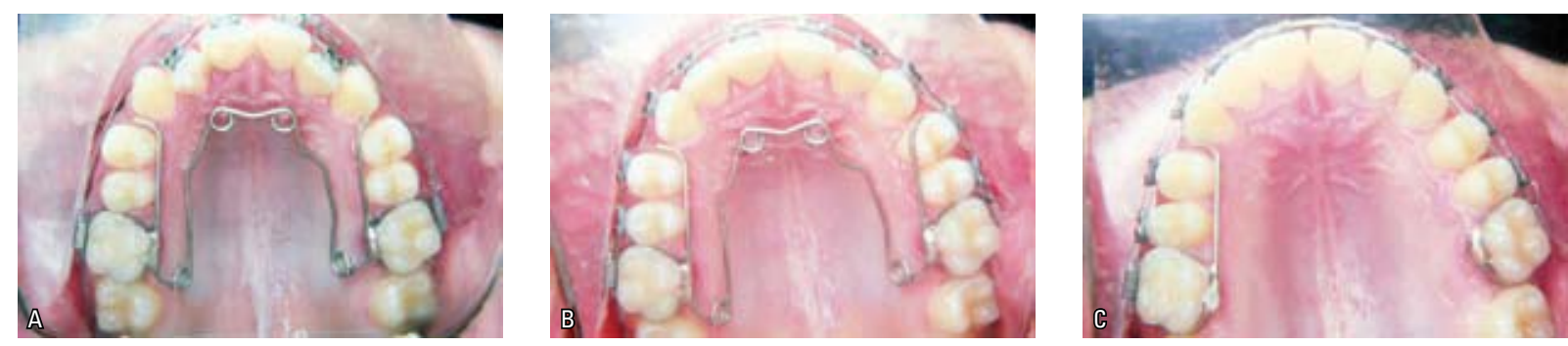

FIGURA 2 - A, B) pode-se observar as ativações tradicionais do quadrihélice, as quais não devem mais ser realizadas desse modo. C) pode-se ver a manutenção do braço lateral do quadrihélice proporcionando estabilidade à correção da má oclusão.
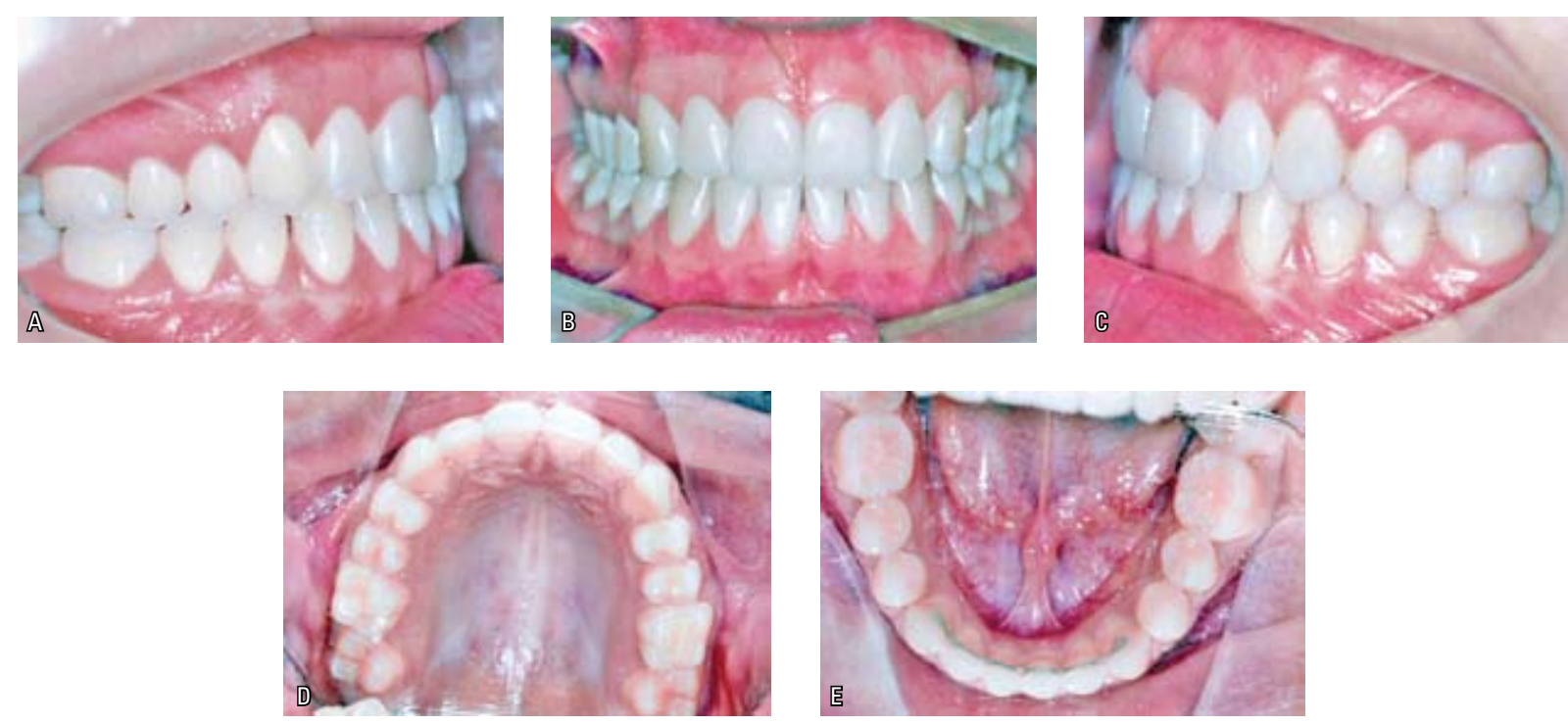

FIGURA 3 - As figuras mostram a estabilidade da correção da mordida cruzada bilateral, um ano e seis meses pós-tratamento.

como de caráter científico, sem levar em consideração todas as informações pertinentes ao cefalograma de norma frontal. É um dever de toda a comunidade ortodôntica fazer uso rotineiro da cefalometria póstero-anterior para retirá-la do ostracismo em que se encontra. Por exemplo, se o problema é esquelético, é de suma importância saber se ele está sendo originado pela atresia da maxila ou se a mandíbula é larga demais. Como resposta, o cefalograma da PA permite avaliar a atresia da maxila por meio da distância do ponto julgal (J) ao plano frontofacial. Assim, podemos analisar o hiperdesenvolvimento ou hipodesenvolvimento de um dos maxilares pela simetria postural da mandíbula e por meio da inclinação do plano oclusal (a qual está quase sempre rela- cionada com o desenvolvimento assimétrico das cavidades nasais). Quando observamos perda da função nasal, podemos encontrar inibição de crescimento ${ }^{16}$. É muito comum, para quem faz uso da PA, encontrar pacientes com obstrução nasal unilateral e observar que toda a maxila, de um lado, está aquém do seu crescimento enquanto, do outro lado, o desenvolvimento realiza-se dentro de uma taxa de normalidade. Portanto, a largura nasal possui uma estreita relação com o desenvolvimento dos maxilares, atuando como uma fantástica matriz funcional de crescimento, ou seja, a cavidade nasal é uma parte vegetativa vital da face. Muitas vezes, abordamos a cavidade bucal como se ela fosse independente do desenvolvimento do primeiro arco branquial, e não dependesse da 
respiração. Biologicamente, as funções da mastigação e da respiração estiveram conectadas com a mesma configuração de músculos e de nervos. Por conseguinte, não podemos estabelecer diagnóstico e plano de tratamento que as separem.

Uma das fases do tratamento ortodôntico corretivo consiste no alinhamento e nivelamento do arco dentário. Em relação a essa fase inicial de tratamento, o quadrihélice a abrevia em 4 a 5 meses, devido ao aumento do perímetro dos arcos dentários. E isso contribui para a diminuição do número de consultas, pois o quadrihélice deve ser ativado a cada 40 ou 50 dias. O tempo de trabalho (cadeira) sofre uma redução significante.

\section{REVISÃO DA LITERATURA}

Bench, Gugino e Hilgers ${ }^{3}$ relataram que existem três métodos para eliminar a discrepância negativa do comprimento de arco:

1) expansão dos segmentos laterais inferiores;

2) avanço dos incisivos inferiores;

3) verticalização ou movimento distal dos molares inferiores.

Essas condutas têm que, obrigatoriamente, levar em consideração os Objetivos Visuais de Tratamento (VTO) ${ }^{12}$ a curto e a longo prazo, pois elas são a base sobre a qual a estética, a estabilidade e a função são efetivadas.

Sellke ${ }^{20}$ comentou que o aparelho quadrihélice e suas variações têm indicação em quase $80 \%$ dos tratamentos ortodônticos.

Haas $^{11}$ e Wertz ${ }^{22}$ mostraram que alguns aparelhos de expansão rígida produzem uma força de separação ortopédica que atinge uma escala de pressão altamente significante. Essa força ortopédica, relativamente pesada, é capaz de produzir uma separação da sutura mesopalatina de 10 a $15 \mathrm{~mm}$. O aparelho quadrihélice expande menos a maxila que o expansor de Haas, pois tem sido observado que ele produz forças no alcance de 2 a 6 newtons. Esses níveis de força estão bem abaixo daqueles mostrados pelo expansor de parafuso.

Frank e Enge ${ }^{10}$ estudaram cefalometricamente o uso do aparelho quadrihélice em 20 pacientes entre 7 e 13 anos de idade para as meninas; e 7 e 17 anos de idade para os meninos, e encontraram em suas amostras os seguintes resultados:

1) suave separação da sutura mesopalatina de 0,92mm em média, porque 5 dos 20 casos apresentaram uma expansão esquelética de mais de $2,7 \mathrm{~mm}$;

2) a maioria das alterações foi de natureza ortodôntica; a média da expansão intermolar foi de $5,88 \mathrm{~mm}$, enquanto nos caninos foi de $2,74 \mathrm{~mm}$;

3) em seu estudo também concluíram que, com o uso do aparelho quadrihélice, houve uma relação de 6:1 no que concerne à expansão ortodôntica em oposição à ortopédica.

Nos tratamentos de arcos superiores restritos, o quadrihélice inclina os molares superiores e os seus processos alveolares para o vestíbulo da cavidade bucal. Os resultados da inclinação acarretam a deformação dos processos alveolares. Portanto, os pacientes que apresentam curva reversa de Wilson (negativa), nos quais os processos alveolares estão
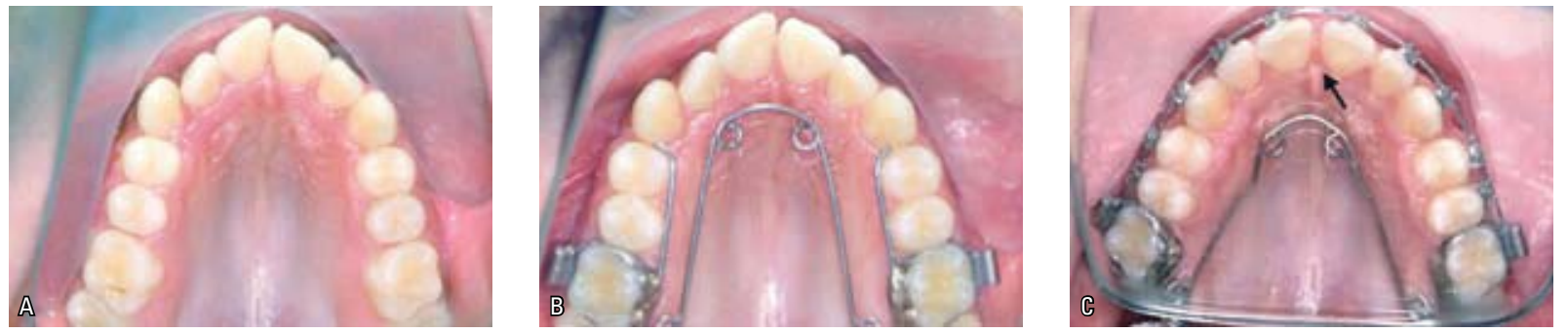

FIGURA 4 - Observe a discreta abertura da sutura mesopalatina após a ativação de expansão do quadrihélice. 


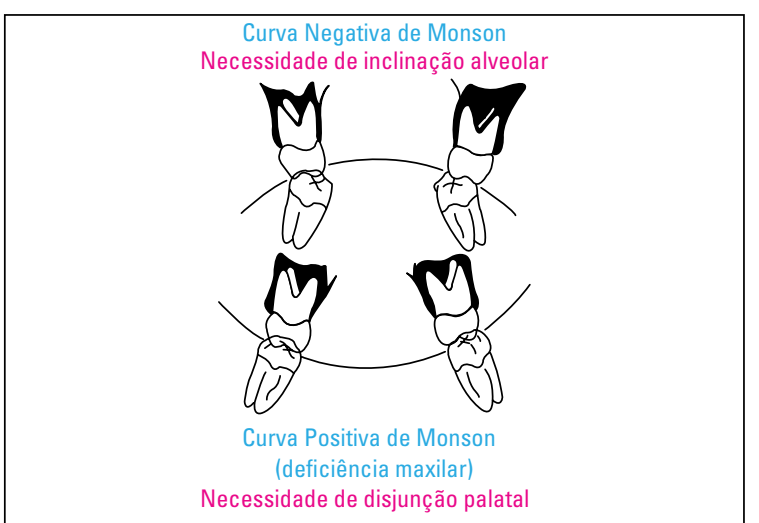

FIGURA 5 - Devemos respeitar a inclinação lingual dos molares na decisão da escolha do método de tratamento das deficiências transversais.

* Fonte: BENCH e cols., 1978.

inclinados para o palato, são os melhores candidatos para a expansão dentoalveolar. No entanto, se houver a necessidade de se promover oposição à ação de inclinação para a vestibular dos dentes de ancoragem, pode ser colocado nas bandas dos molares, antes da cimentação, torque vestibular de raiz.

Se os molares superiores requererem rotação, toda a força de expansão será dirigida a esses dentes nas fases iniciais de tratamento. Com a rotação dos molares superiores, os braços palatinos do aparelho encostam-se às faces palatinas dos dentes dos segmentos látero-superiores do arco. Quando

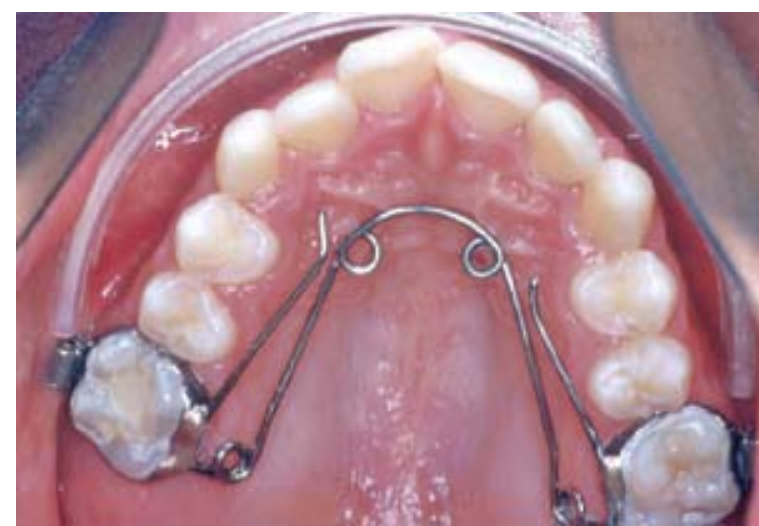

FIGURA 6 - Observe como os braços laterais do quadrihélice ficam afastados dos dentes látero-posteriores para permitir, prontamente, a rotação e a distalização dos molares superiores.

isso acontece, a força de expansão nos molares é reduzida.

As figuras 7, 8, 9, 10 e 11 ilustram todos os procedimentos de ativação do quadrihélice.

Preconizamos que todas essas ativações sejam realizadas em intervalos que variam de 40 a 60 dias; no entanto, muitas vezes, a ativação pode ser única. Devemos ter em mente que ativações efetuadas em intervalos menores do que esses criam um precedente para se trabalhar com forças antibiológicas pelo efeito acumulativo. Além disso, o processo fisiológico de deformação dos processos alveolares, de alteração dos ligamentos

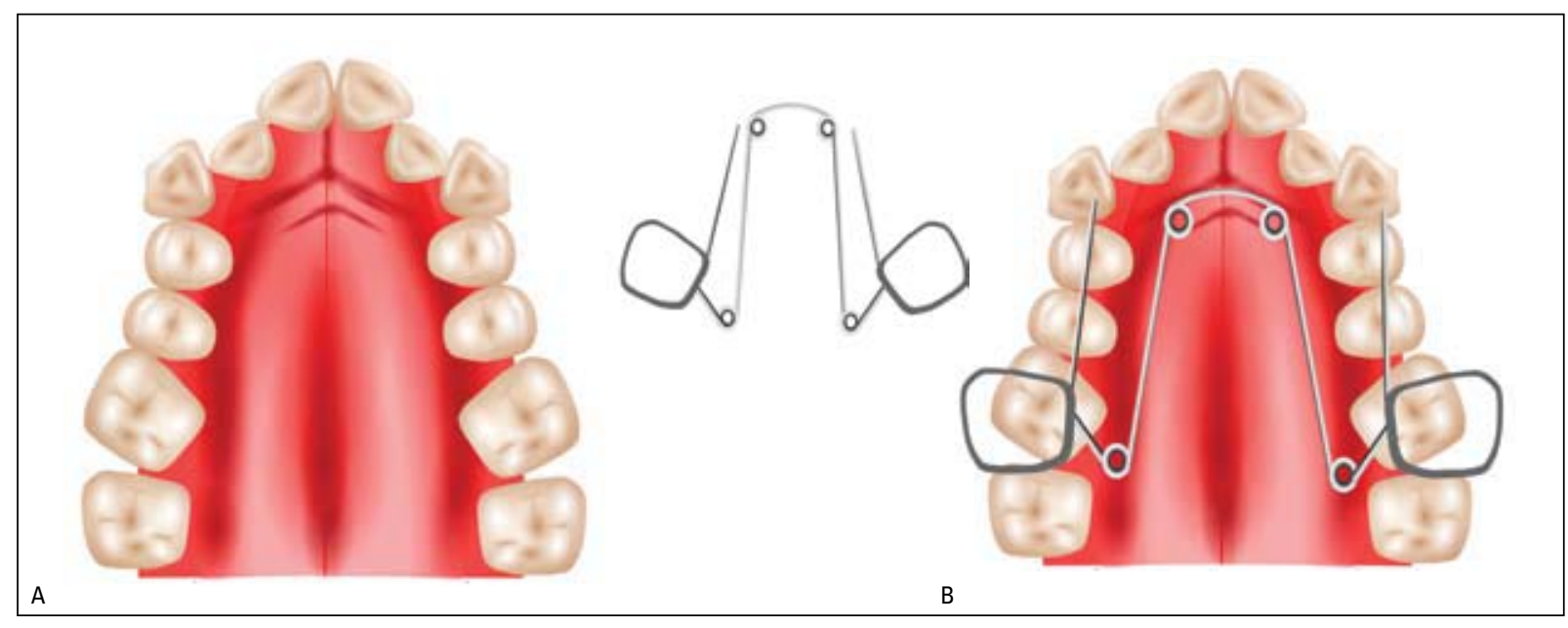

FIGURA 7 - A) antes da ativação; B) ativação de rotação molar, realizada diretamente nas bandas dos molares superiores. 


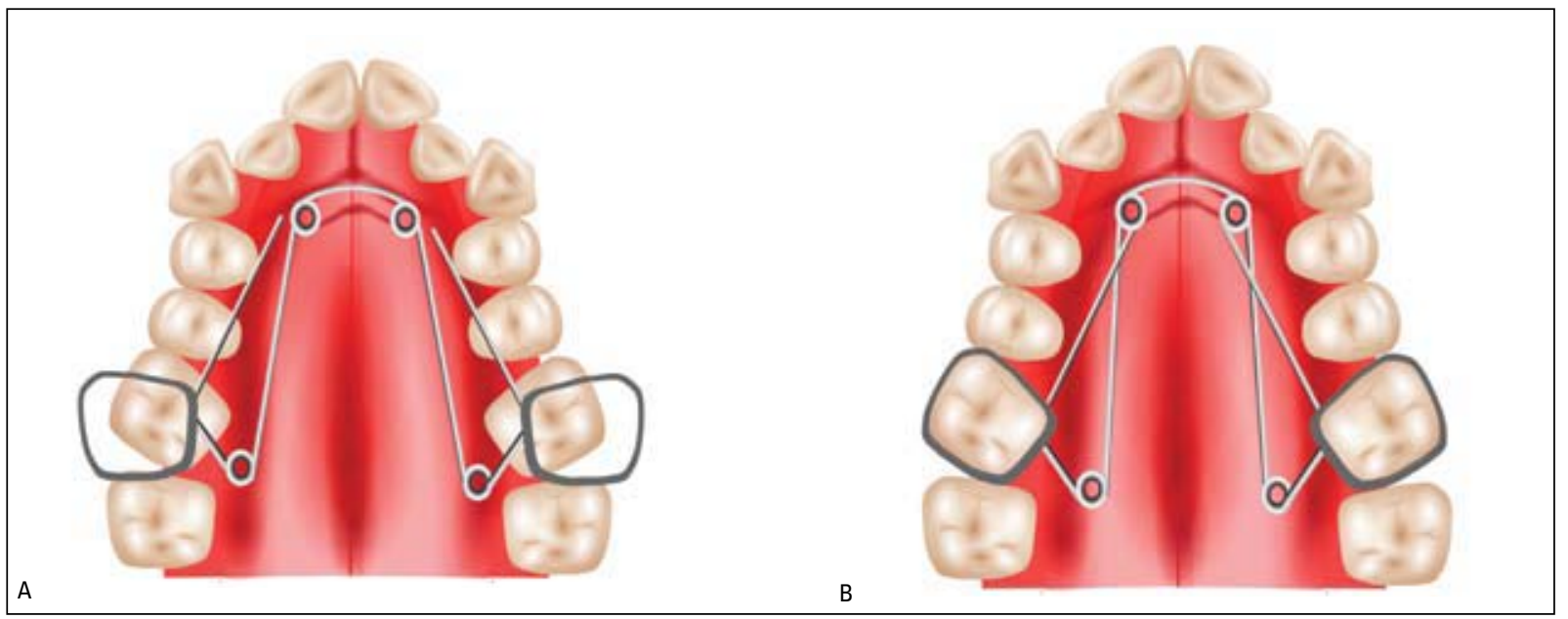

FIGURA 8 - As ilustrações mostram a retirada do contato da haste lateral do quadrihélice com os dentes látero-posteriores.

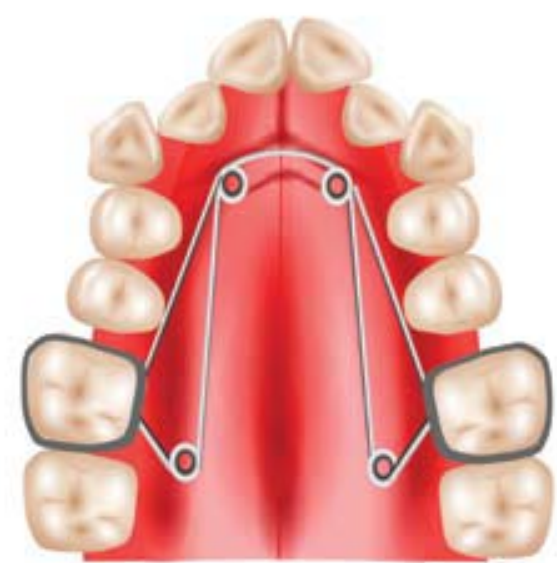

FIGURA 9 - Observe que, quando os molares superiores sofrem rotação, seguida de distalização, o segmento lateral do quadrihélice entra naturalmente em contato com os dentes látero-superiores, iniciando a expansão desses lementos.

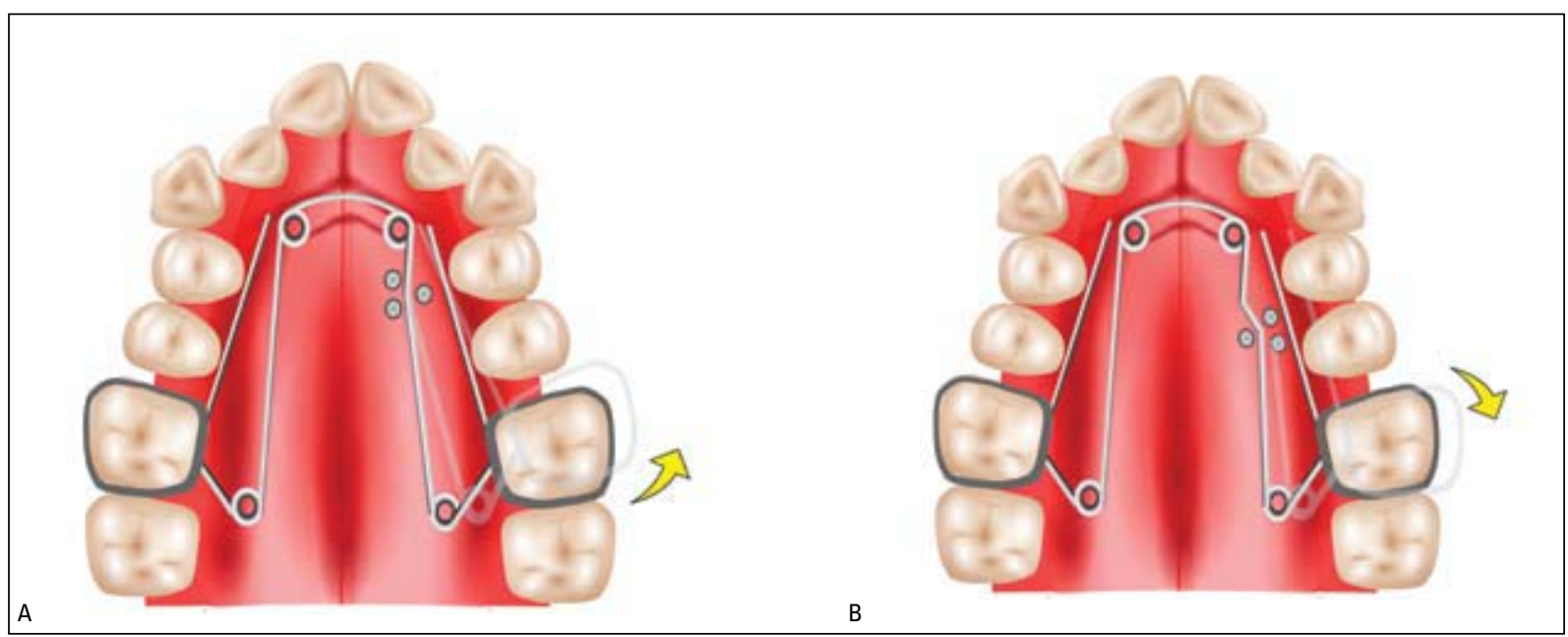

FIGURA 10 -A) A primeira ativação intrabucal realizada com o alicate de três pontas proporciona expansão com tendência de mesialização dos molares; B) a segunda ativação submete os molares aos movimentos de rotação e distalização. 


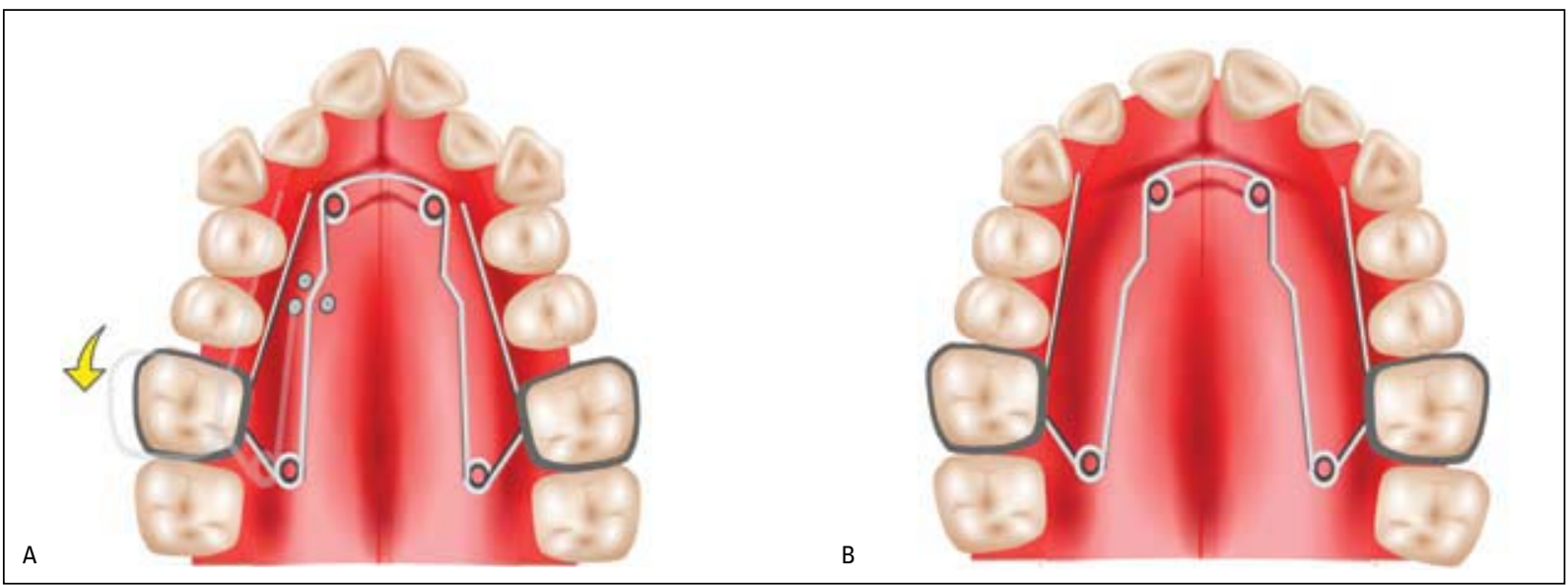

FIGURA 11 - A) podemos observar a similaridade das ativações; B) observamos a nova forma do arco dentário.

periodontais e de movimento dentário desencadeados pela ação do quadrihélice necessitam de tempo para acontecer e se recompor. São as Leis da Biologia.

Outra alternativa para promover a rotação rápida dos molares é construir o quadrihélice desprovido do setor lateral e efetuar as ativações muito próximas dos helicóides posteriores com o alicate de três pontas (Fig. 12).

Em muitas circunstâncias, a rotação molar efe-
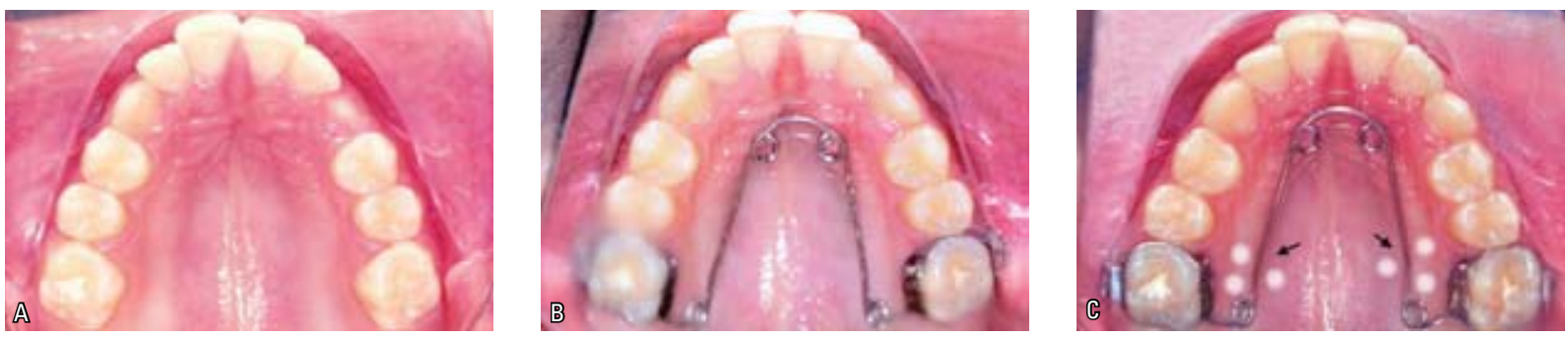

FIGURA 12 - A) Início; B) logo após a cimentação do quadrihélice; C) ativação intrabucal.

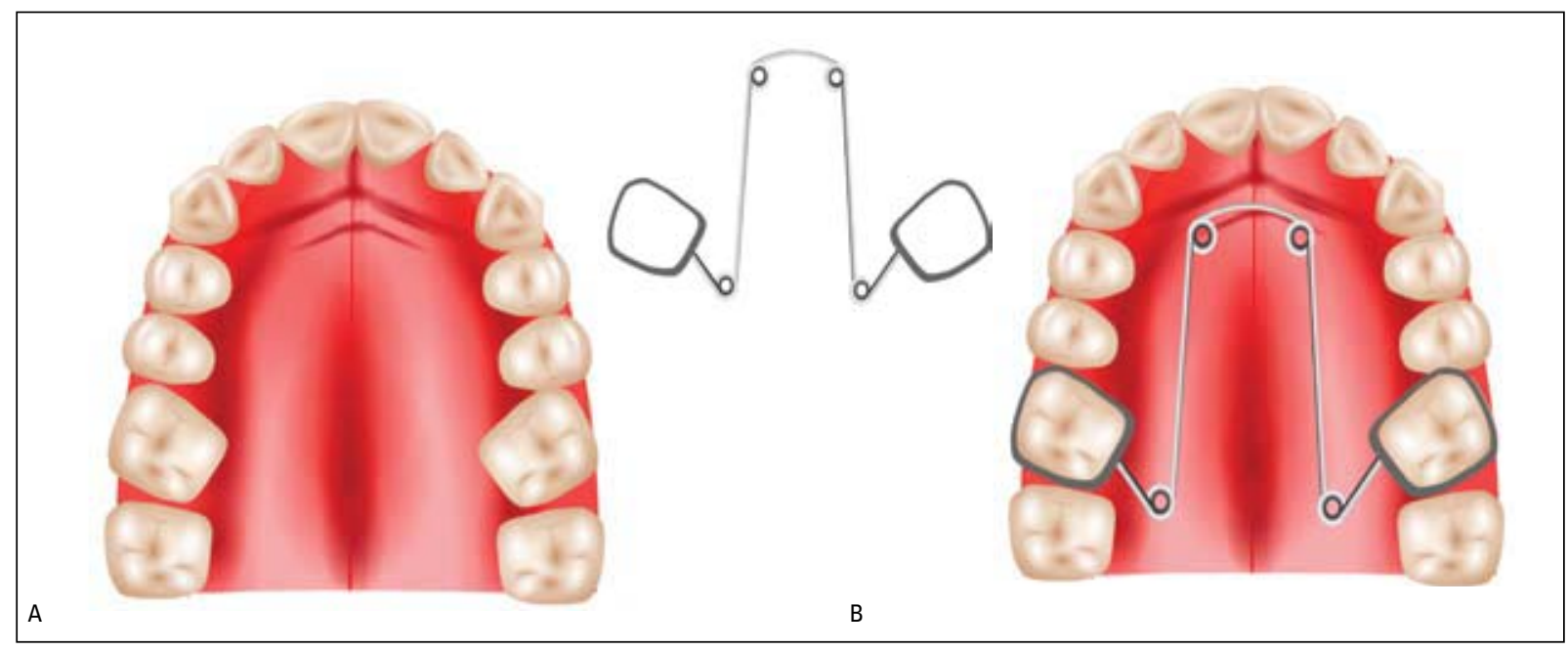

FIGURA 13 - A) podemos observar a rotação mesial excessiva dos molares superiores; B) quadrihélice passivo de ativação. 


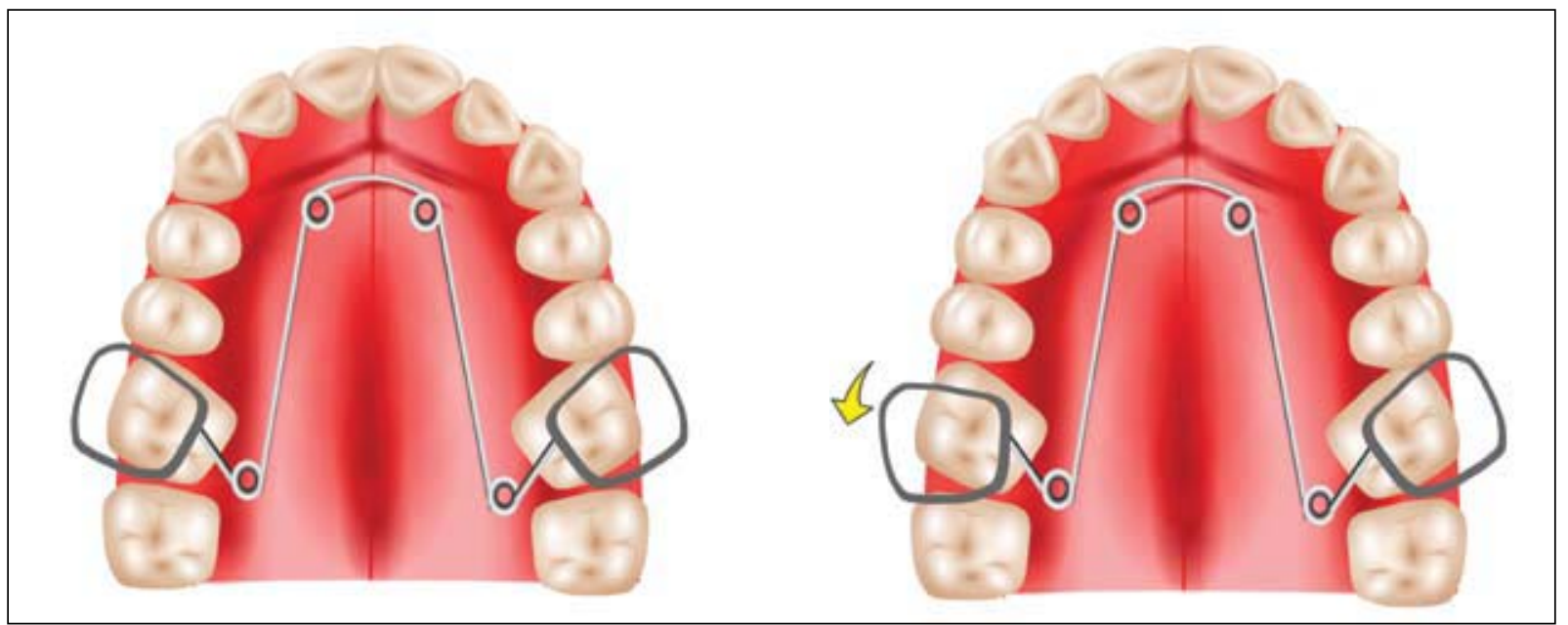

FIGURA 14 - As ilustrações mostram a ativação de rotação das bandas dos molares superiores.

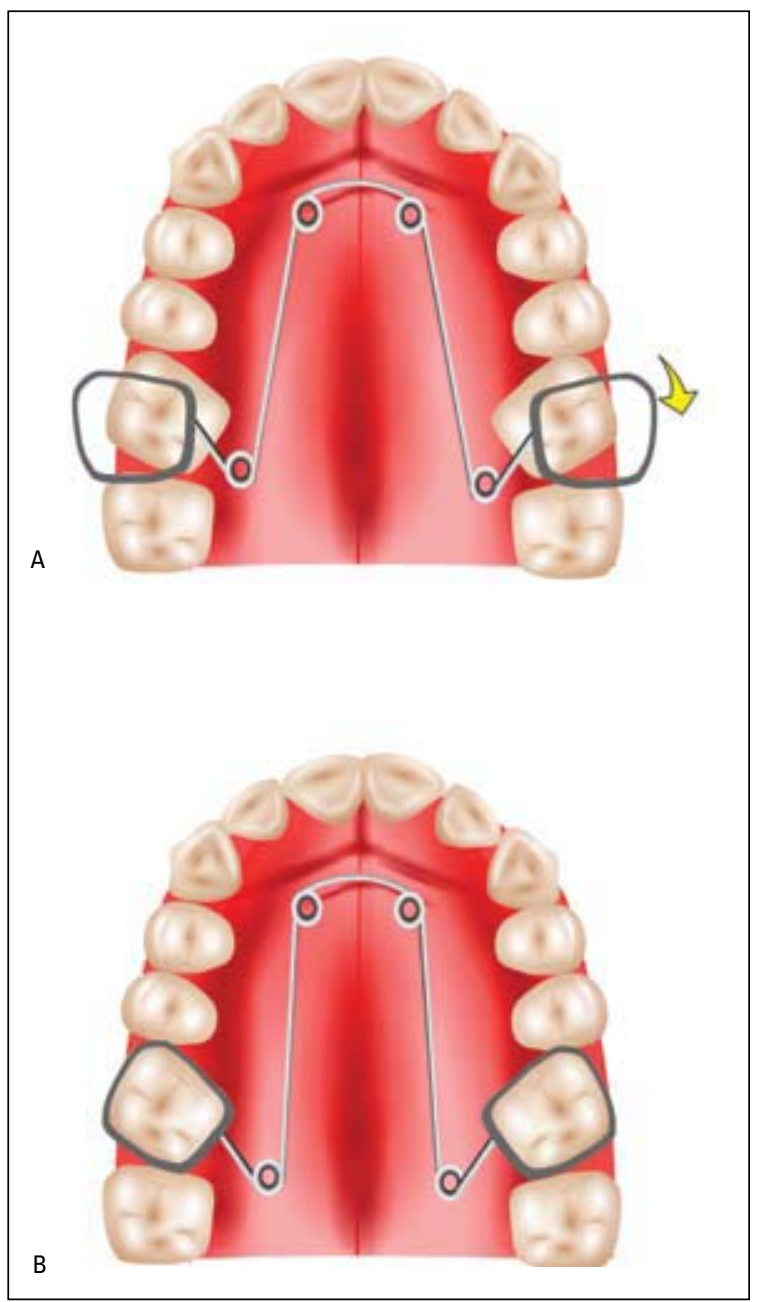

FIGURA 15 - A) Situação final das ativações incorporadas ao aparelho antes da sua cimentação; B) quadrihélice cimentado aos dentes molares.

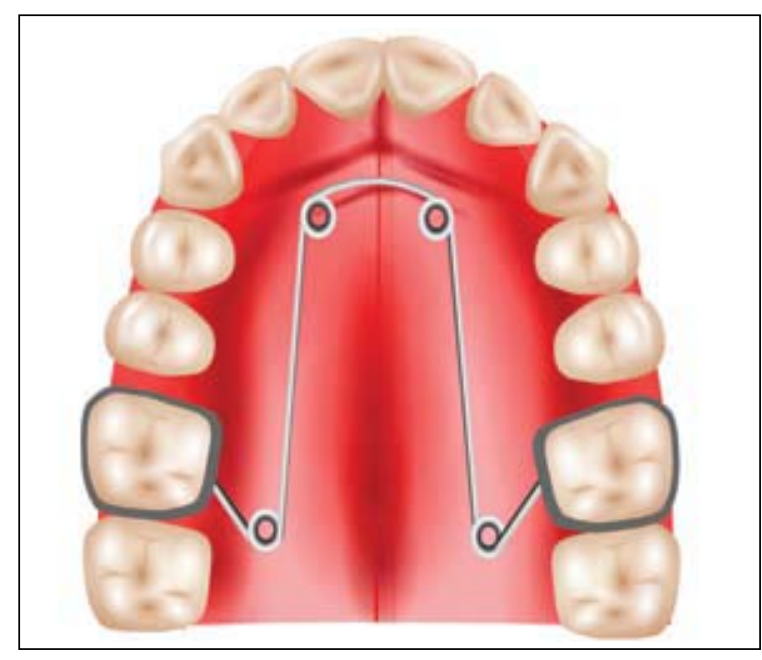

FIGURA 16 - Ganho de espaço no arco dentário devido à rotação dos mo lares.

tuada pelo aparelho quadrihélice ocasiona uma distalização dos molares suficiente para solucionar a relação molar de Classe II com degrau reto. Uma quantidade de 3 a $5 \mathrm{~mm}$ de comprimento de arco é conseguida com a rotação e a distalização dos molares pela correta ativação do quadrihélice. A quantidade de movimento distal dos molares superiores está relacionada com o mesoposicionamento dos mesmos. A vantagem de ativar o quadrihélice dessa maneira é que ele permite que, de fato, os dentes superiores sejam expandidos de um 

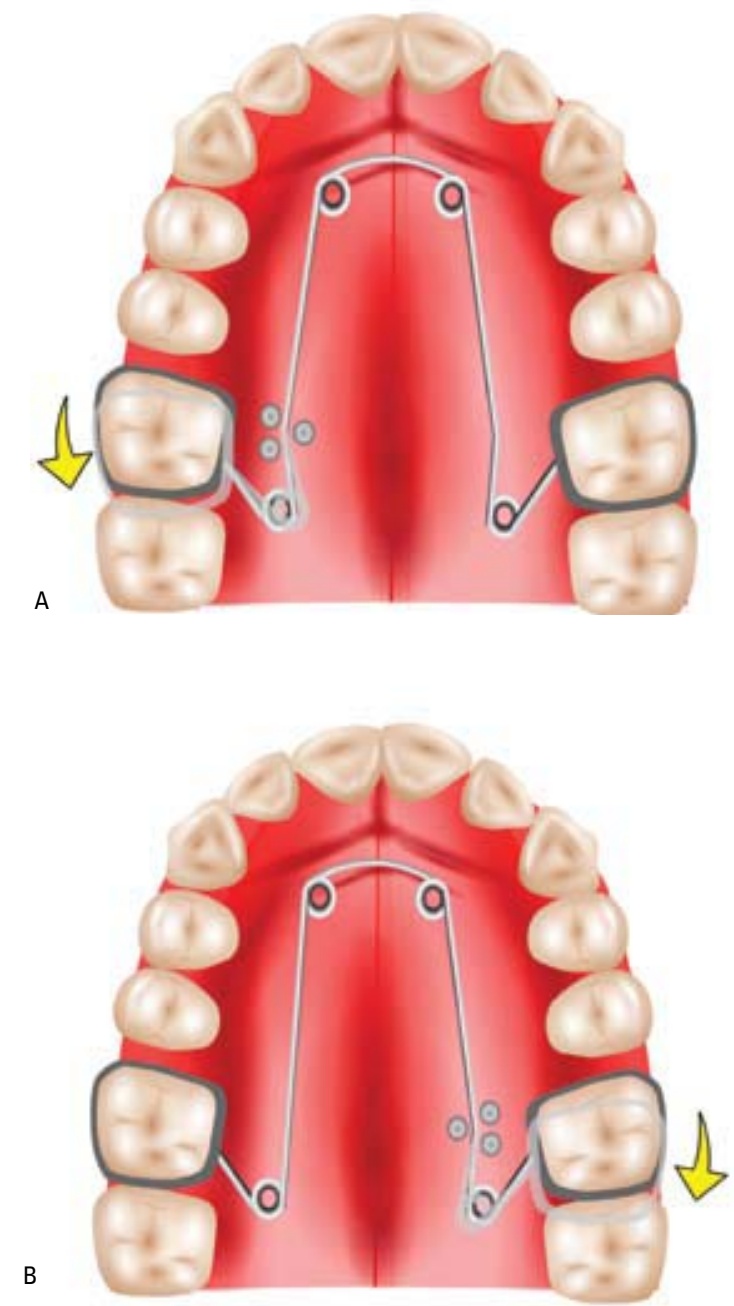

FIGURA 17 -A, B) ilustram de que forma podemos aumentar esse espaço com as ativações intrabucais realizadas com o alicate de três pontas

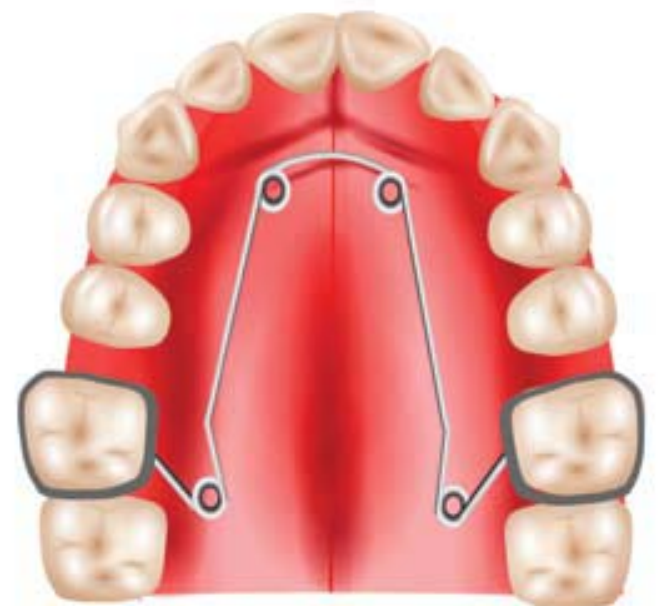

FIGURA 18 - Resultado final esperado com as corretas ativações do aparelho quadrihélice. 
modo diferencial, o que os conduz para atingir a forma de um dos arcos pentamórficos de Ricketts $^{15}$, ou seja, a forma da oclusão final.

O caso a seguir (Fig. 19, 20) mostra a eficiência dessa ativação. $\mathrm{O}$ paciente apresentava falta de espaço para o canino superior esquerdo devido à mesialização do molar nesse mesmo quadrante, estabelecendo uma relação molar de Classe II. O quadrihélice foi ativado próximo ao helicóide posterior, do lado oposto à relação molar de Classe II. Essa ativação irá promover a distalização do molar superior esquerdo, bem como a rotação do molar superior direito. Para neutralizar a rotação do molar superior direito, coloca-se um arco seccional de estabilização construído com fio elgiloy azul 0,016" X 0,016”. Dependendo do caso, essa seção estabilizadora pode ser construída com fio elgiloy 0,016 " X 0,022". Observe na figura 19B que a seção estabilizadora, construída com fio elgiloy 0,016" X 0,016" foi colocada no segundo molar decíduo. Após conseguir a relação molar de Classe I do lado esquerdo, foi aplicado um par de arcos utilitários com a finalidade de nivelar, alinhar e intruir os dentes anteriores dos arcos superior e inferior. Para finalizar, foram utilizados arcos 0,016 " X 0,016", confeccionados com fio elgiloy azul. Todos esses arcos foram coordenados dentro do conceito dos arcos pentamórficos de Ricketts. Esse tratamento exigiu somente essas duas trocas de arcos.

Na maioria dos pacientes, a expansão do arco superior resulta em uma expansão passiva transversal na mandíbula ${ }^{17}$. É uma resposta funcional que ocorre em todo o arco inferior, a qual, extremamente estável, é produzida por meio de ação muscular. Na verdade, é uma reação recíproca de expansão do arco inferior que ocorre por meio da adaptação muscular, como também da função. Desse modo, quanto mais precoce for a intervenção, melhores serão os resultados em longo prazo no que diz respeito à estabilidade, função e integridade das articulações temporomandibulares. Essas, por sua vez, em muitas situações, passam a ser o fator causal da instabilidade e recidi-
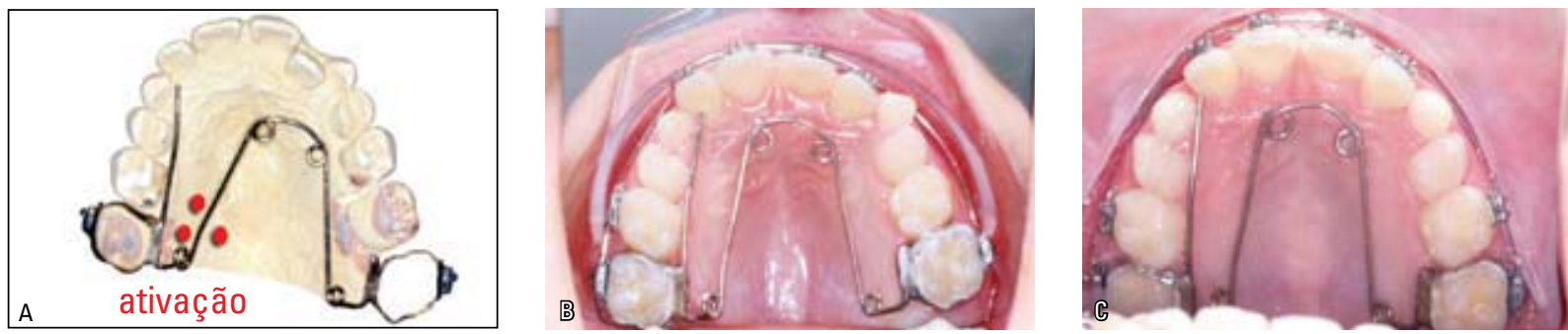

FIGURA 19 - A) mostra-se a quantidade de ativação utilizada; B) o aparelho cimentado; C) pode-se observar a correção da mesoposição do molar superior esquerdo e, assim, a sua harmonia com o molar superior do lado oposto.
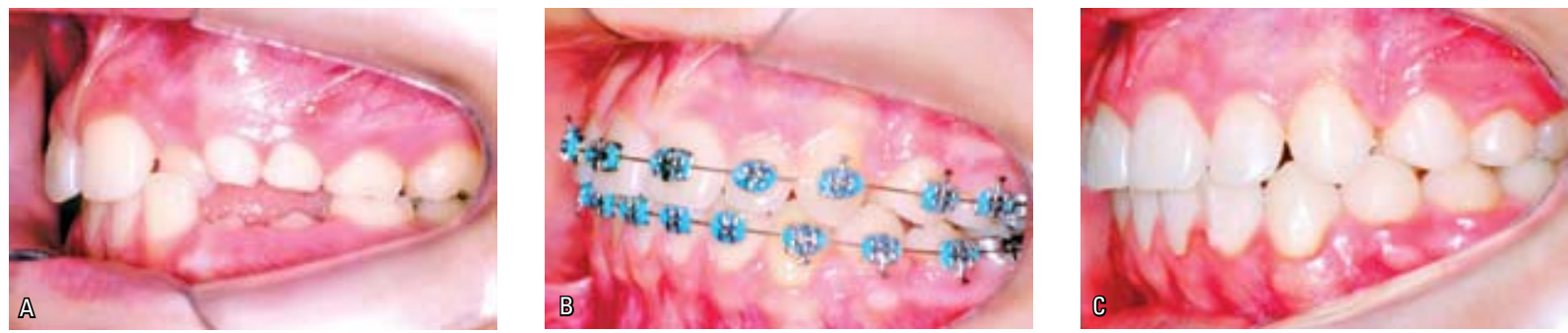

FIGURA 20 - Observe como o aparelho quadrihélice foi efetivo em promover a rotação e a distalização do molar superior esquerdo e, conseqüentemente, a sobrecorreção da Classe II. 
vidade na sobrecorreção das discrepâncias transversais após os 11 anos de idade (portanto, em crianças ainda), devido ao comprometimento das estruturas que as compõem, particularmente quando da associação com problema postural craniocervical, o qual tem potencial de aumentar ainda mais a compressão condilar, provocando um processo disfuncional com remodelagem das estruturas craniomandibulares. Outro fator relevante de associação é o problema da obstrução respiratória unilateral durante toda a infância. Ainda sobre a expansão do arco inferior, às vezes é vantajoso colocar um aparelho bihélice no arco mandibular para obter e manter o equilíbrio nas dimensões dos arcos superior e inferior. Embora exija um pouco de experiência, é possível ativar o quadrihélice, assim como o bihélice, depois que foram cimentados nos molares. Nas circunstâncias em que ativações complexas são requeridas, é aconselhável remover os aparelhos e, então, ativá-los antes da recimentação. Observe o caso clínico a seguir.
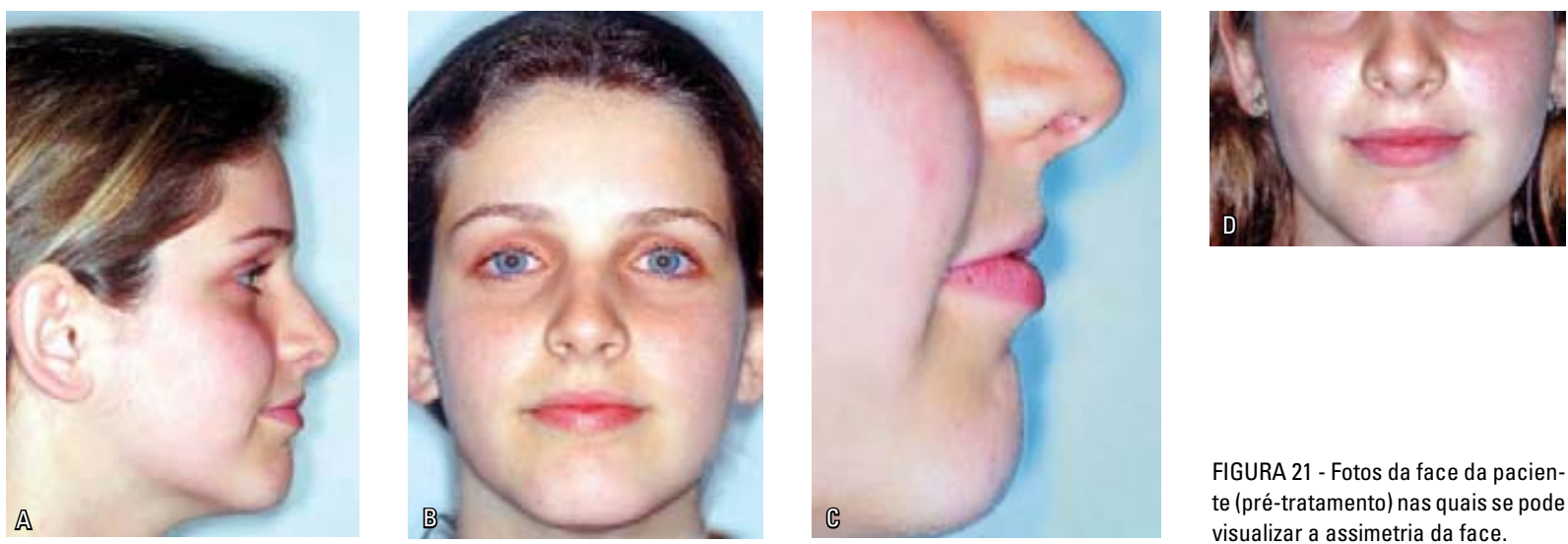

FIGURA 21 - Fotos da face da paciente (pré-tratamento) nas quais se pode visualizar a assimetria da face.
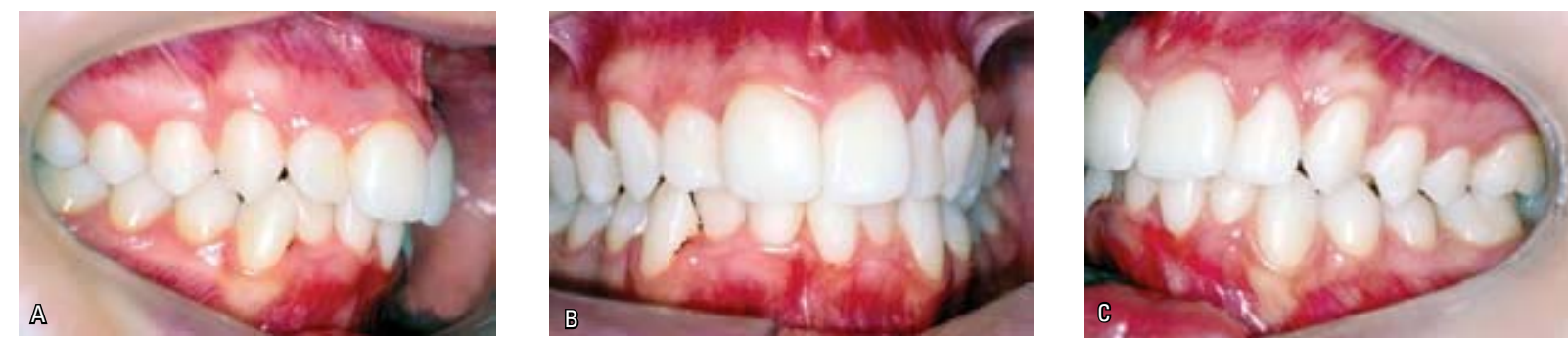

FIGURA 22 - Observar o desvio da linha média.
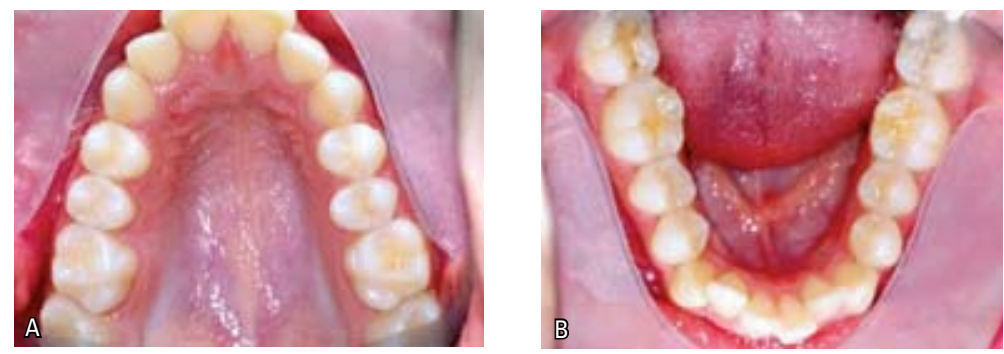

FIGURA 23 - Note o estreitamento dos arcos, bem como a relevante discrepância negativa do arco inferior (- 7mm). 


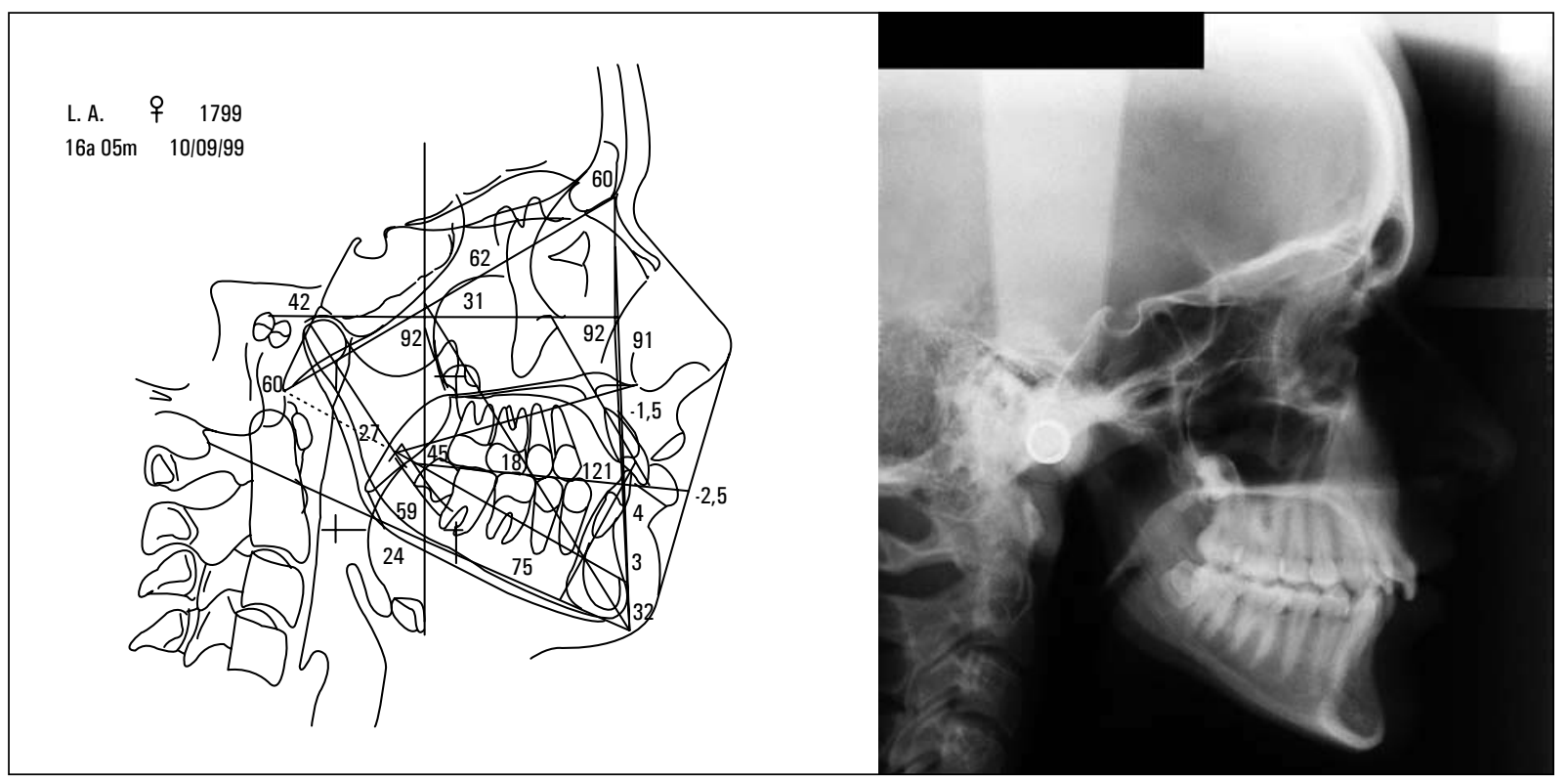

FIGURA 24 - Telerradiografia de norma lateral e cefalograma de Ricketts.

A paciente, leucoderma e de tipologia mesofacial, procurou os nossos serviços devido ao seu descontentamento com o alinhamento dos seus dentes. Ela apresentava assimetria facial e os seus arcos dentários atrésicos. A discrepância dentária negativa do arco inferior era de $7 \mathrm{~mm}$.

Pela interpretação do cefalograma de norma lateral de Ricketts ${ }^{9}$, pode-se constatar que a paciente possuía a relação dental em Classe I, porém a convexidade facial encontrava-se nega-

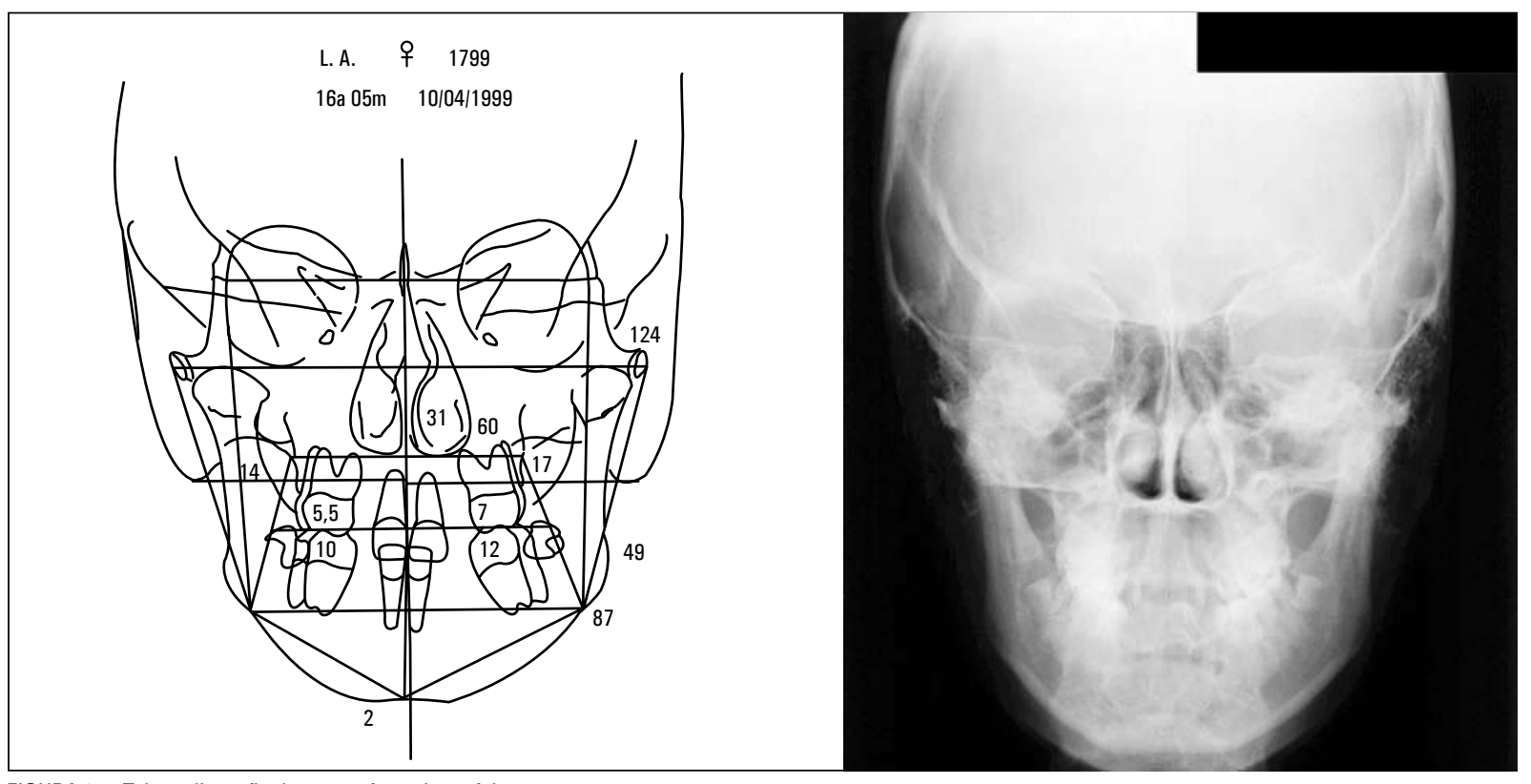

FIGURA 25 - Telerradiografia de norma frontal e cefalograma de Ricketts. 
tiva, ou seja, com $-1,5 \mathrm{~mm}$. Isso ocorreu devido a um discreto mesoposicionamento mandibular (profundidade facial e eixo facial de Ricketts, ambos com $92^{\circ}$ ) e uma suave inadequação do complexo nasomaxilar com a base anterior do crânio (Ba-Na ponto $\mathrm{A}, 60^{\circ}$ ). $\mathrm{Na}$ análise vertical, a paciente apresentava uma satisfatória relação das bases ósseas, porém a altura posterior (59mm) estava diminuída em relação à norma.

A análise dentária, no cefalograma de norma lateral, mostrou que os incisivos inferiores encontravam-se discretamente extruídos. A norma é $1,5 \mathrm{~mm}$ com desvio padrão de $2 \mathrm{~mm}$. Os mesmos estavam distantes do plano oclusal funcional em $4 \mathrm{~mm}$. No plano sagital, os incisivos inferiores estavam localizados a $3 \mathrm{~mm}$ do plano A-Po, portanto dentro da norma cefalométrica ajustada para o padrão latino; no entanto, exibiam uma inclinação discretamente acima da norma. Já os molares superiores se apresentavam bem relacionados com a vertical pterigóide e posicionados bem abaixo do eixo facial de Ricketts. Isso mantém o plano oclusal funcional abaixo do ponto cefalométrico $\mathrm{Xi}$. Normalmente, os pacientes que exibem esse tipo de relacionamento apresentam um bom crescimento mandibular. $\mathrm{O}$ arco mandibular de $27^{\circ}$, abaixo da norma, alerta que deveríamos adotar uma biomecânica não-extrusiva nos molares inferiores, com a finalidade de promover o controle rotacional da mandíbula.

A cefalometria de norma póstero-anterior confirmou a tipologia mesofacial da paciente por meio do fator cefalométrico largura facial $(124 \mathrm{~mm})$. O espaço aéreo estava satisfatório, porém a paciente apresentava a base óssea superior atrésica (60 $\mathrm{mm})$ e a largura mandibular normal $(87 \mathrm{~mm})$. Isso fez com que os pontos J, direito e esquerdo, ficassem distantes do plano maxilo-mandibular $(14 \mathrm{~mm}$ e $17 \mathrm{~mm}$, respectivamente). Nessas circunstâncias, o dispositivo recomendado pela cefalometria frontal é o disjuntor palatal, com o intuito de restabelecer a norma cefalométrica à maxila; porém, devido ao fator cronológico, foi descartado o uso desse aparelho. Em relação aos dentes, os molares superiores e inferiores estavam consideravelmente distantes do plano julgal. Alem disso, estava comprometida a distância entre os molares inferiores, cuja norma é de $55 \mathrm{~mm} \pm 2 \mathrm{~mm}$ (a mesma apresentava $49 \mathrm{~mm}$ ). Desse modo, o protocolo recomendado foi a instalação de um dispositivo com a finalidade de promover a expansão dentoalveolar. Assim, foi instalado na paciente o aparelho quadrihélice no arco superior e o aparelho bihélice no arco inferior. A expectativa era de recuperar os $7 \mathrm{~mm}$ de discrepância dentária que a paciente apresentava somente por meio da expansão do arco inferior, pois as medidas transversais do referido arco estavam com os seus valores muito discrepantes em relação à norma. A regra preditiva de ganho de espaço no arco inferior, levando-se em consideração a expansão dos arcos dentários, é mostrada na tabela 1.

Desse modo, quando os valores da largura dentária do arco inferior estiverem discrepantes em relação aos valores normativos e, conseqüentemente, a quantidade de expansão necessária para restabelecer esses valores se enquadrar aos números citados na tabela 1 , é estimado um aumento no perímetro do arco em um milímetro para cada procedimento. É evidente que devemos ter em mente a individualização do planejamento ortodôntico, respeitando a tipologia facial do paciente, a estética do sorriso, a proporção divina da largura nasal com a largura da boca, bem como requerimentos da oclusão funcional.

Tabela 1 - Estimativa de ganho de espaço para o arco inferior mediante a expansão dos dentes látero-inferiores.

\begin{tabular}{cccc}
\hline $\begin{array}{c}\text { Distância inter- } \\
\text { dental }\end{array}$ & $\begin{array}{c}\text { Valores } \\
\text { normativos }\end{array}$ & $\begin{array}{c}\text { Quantidade } \\
\text { de expansão }\end{array}$ & $\begin{array}{c}\text { Estimativa de } \\
\text { ganho de espaço }\end{array}$ \\
$\begin{array}{c}\text { Primeiros } \\
\text { molares }\end{array}$ & $55 \mathrm{~mm} \pm 2$ & $4 \mathrm{~mm}$ & $1 \mathrm{~mm}$ \\
$\begin{array}{c}\text { Segundos pré- } \\
\text { molares }\end{array}$ & $46 \mathrm{~mm} \pm 2,4$ & $3 \mathrm{~mm}$ & $1 \mathrm{~mm}$ \\
$\begin{array}{c}\text { Primeiros pré- } \\
\text { molares }\end{array}$ & $40 \mathrm{~mm} \pm 2$ & $2 \mathrm{~mm}$ & $1 \mathrm{~mm}$ \\
Caninos & $26 \mathrm{~mm} \pm 2$ & $1 \mathrm{~mm}$ & $1 \mathrm{~mm}$ \\
\hline
\end{tabular}




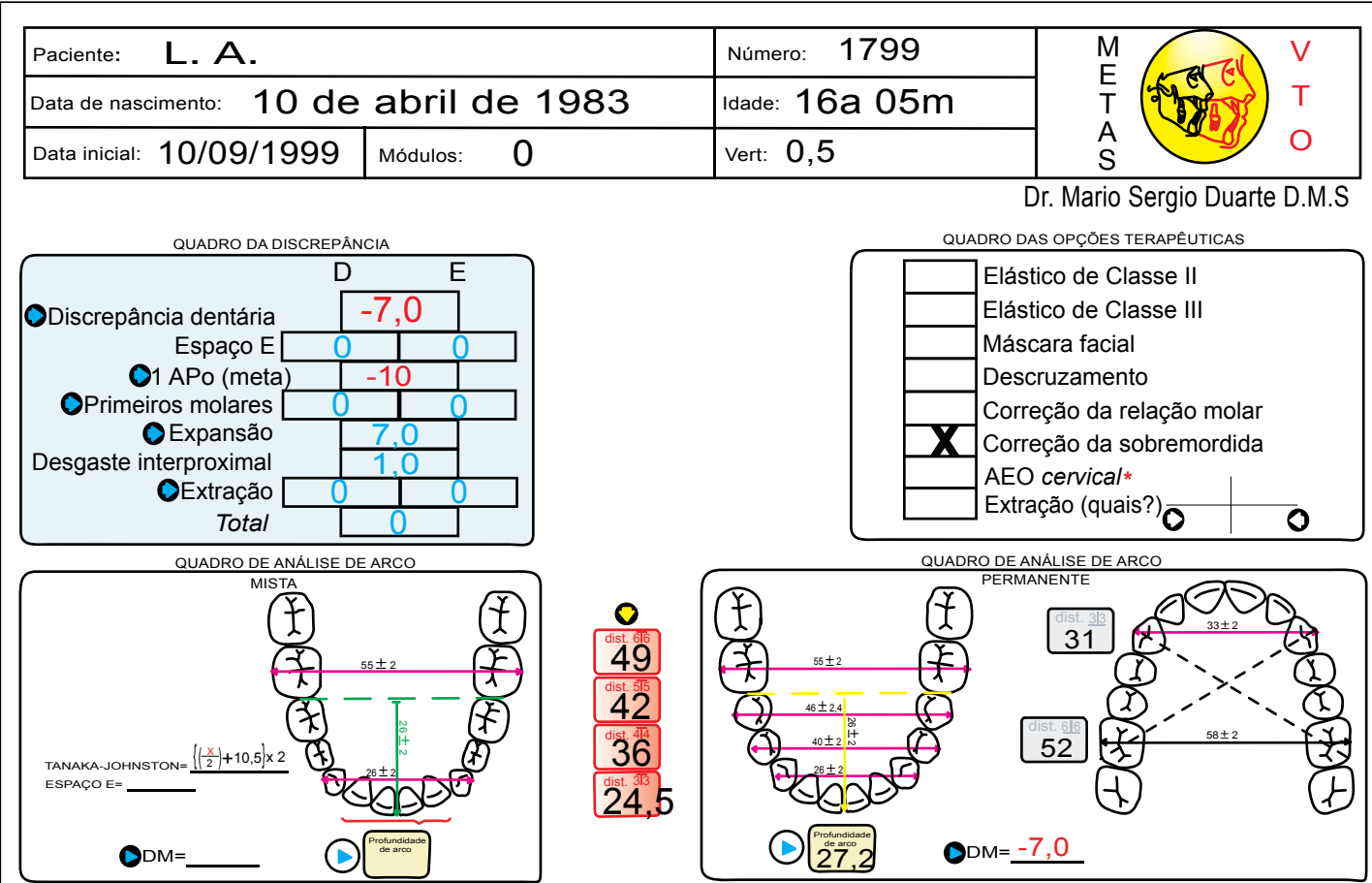

QUADRO DAS METAS

convexidade

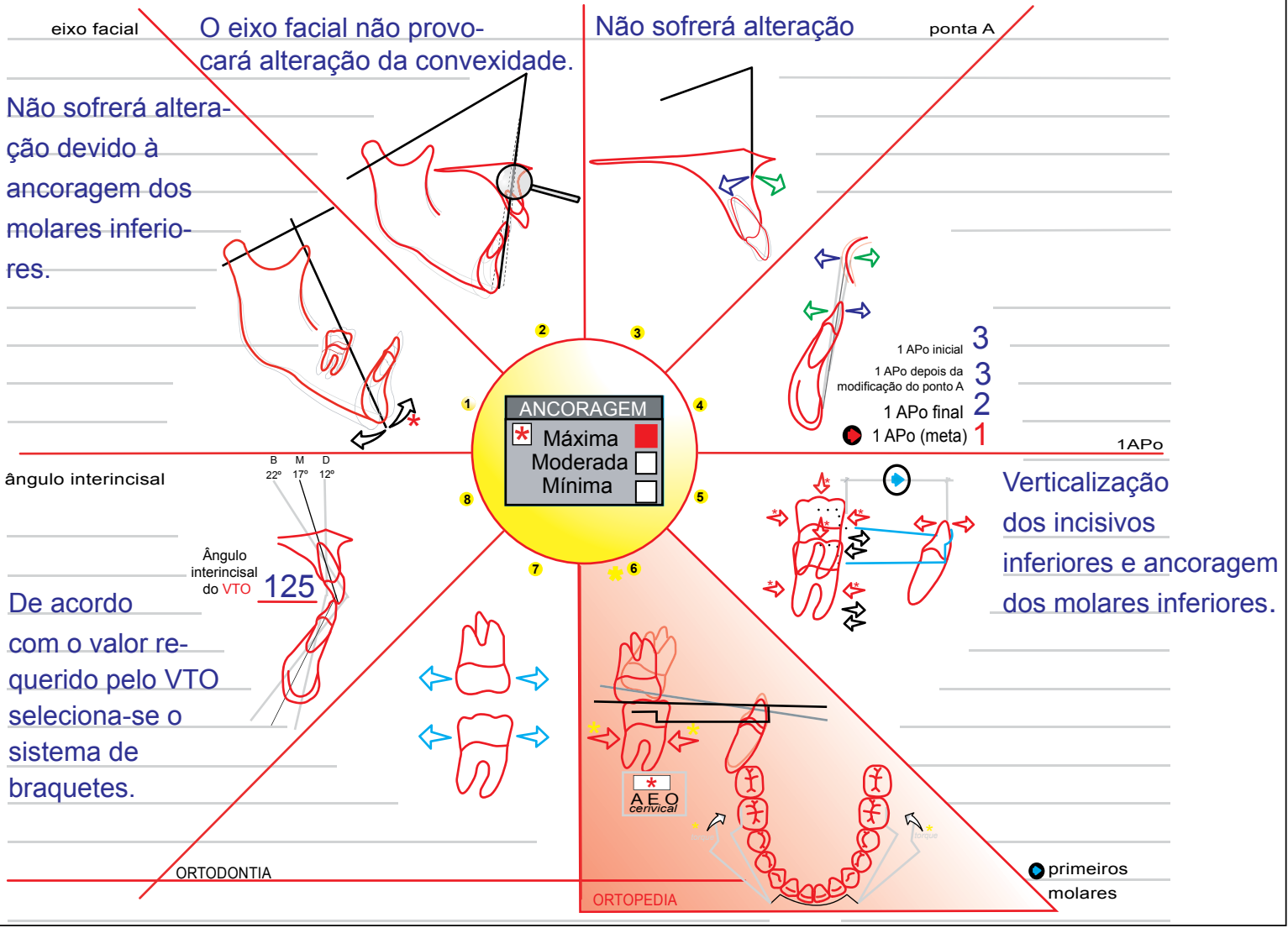

FIGURA 26 - Metas para a construção do VTO7. 


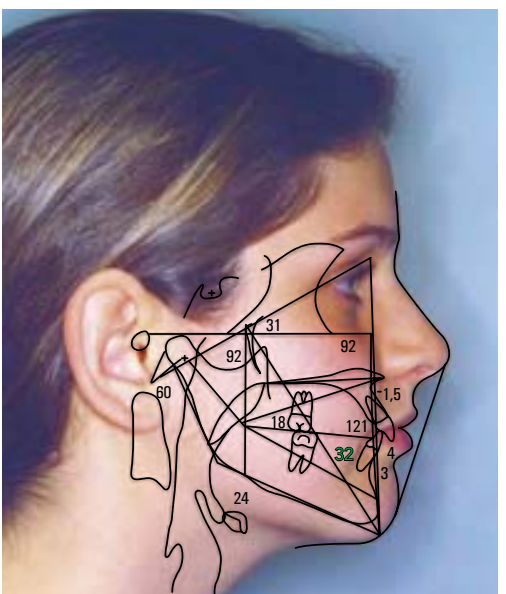

FIGURA 27 - Traçado cefalométrico de Ricketts sobreposto à face da paciente.

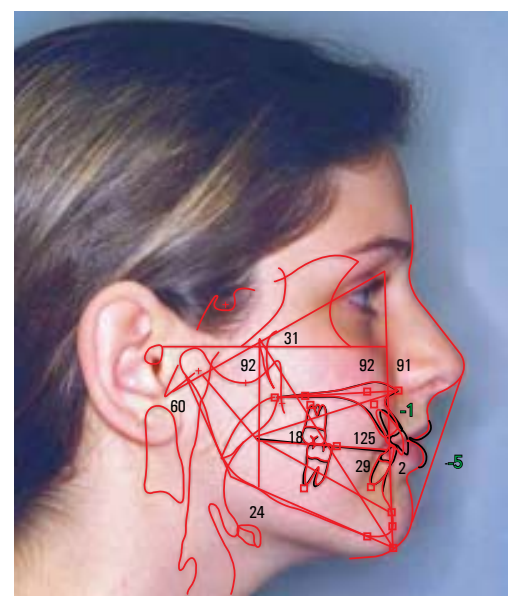

FIGURA 28 - Observe as alterações esperadas decorrentes das biomecânicas a serem empregadas previstas pela Visualização dos Objetivos do Tratamento (VTO).

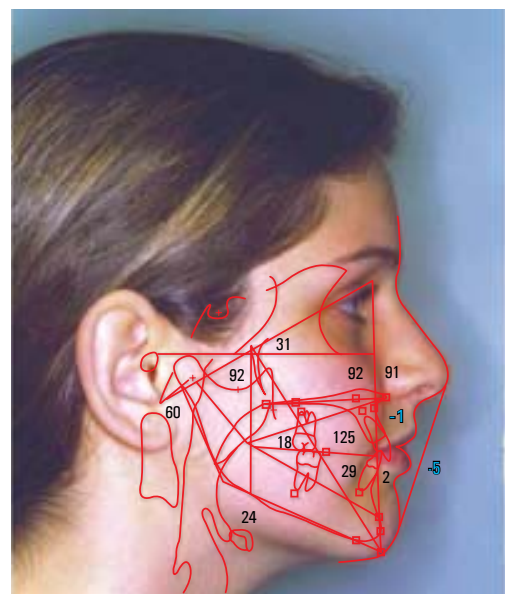

FIGURA 29 - Visualização dos Objetivos do Tratamento (VTO). Observe o resultado esperado das alterações dos tecidos moles decorrentes do tratamento.

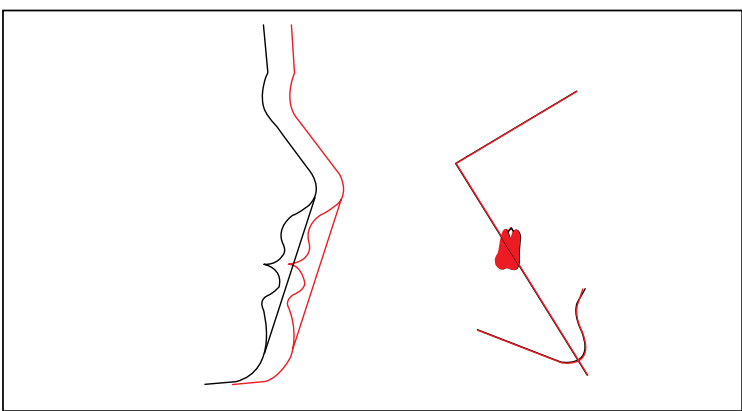

FIGURA 30 - Projeção de uma discreta alteração dos tecidos moles e manutenção do eixo facial.
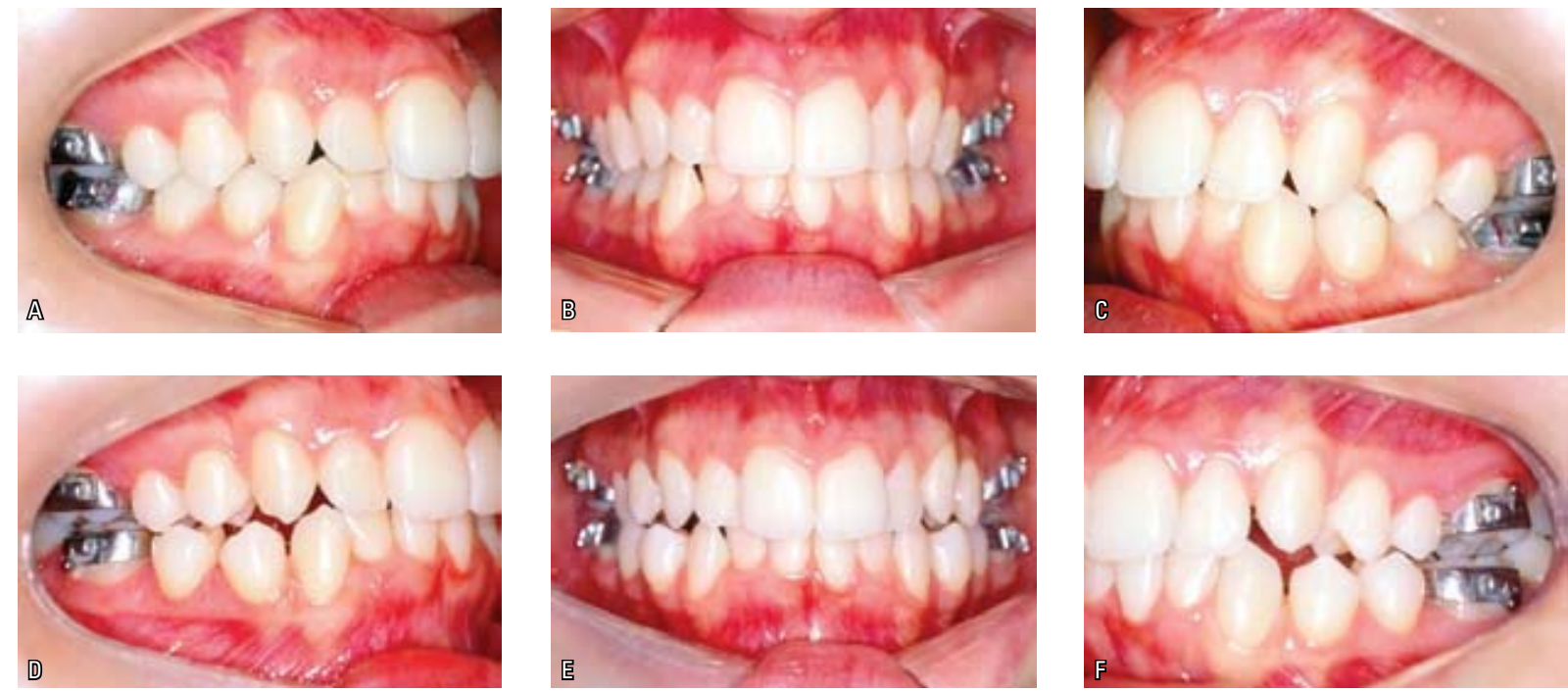

FIGURA 32 - A, B, C) mostram o momento inicial da cimentação dos aparelhos; D, E, F) mostram o caso clínico após cinco meses da instalação dos aparelhos. 

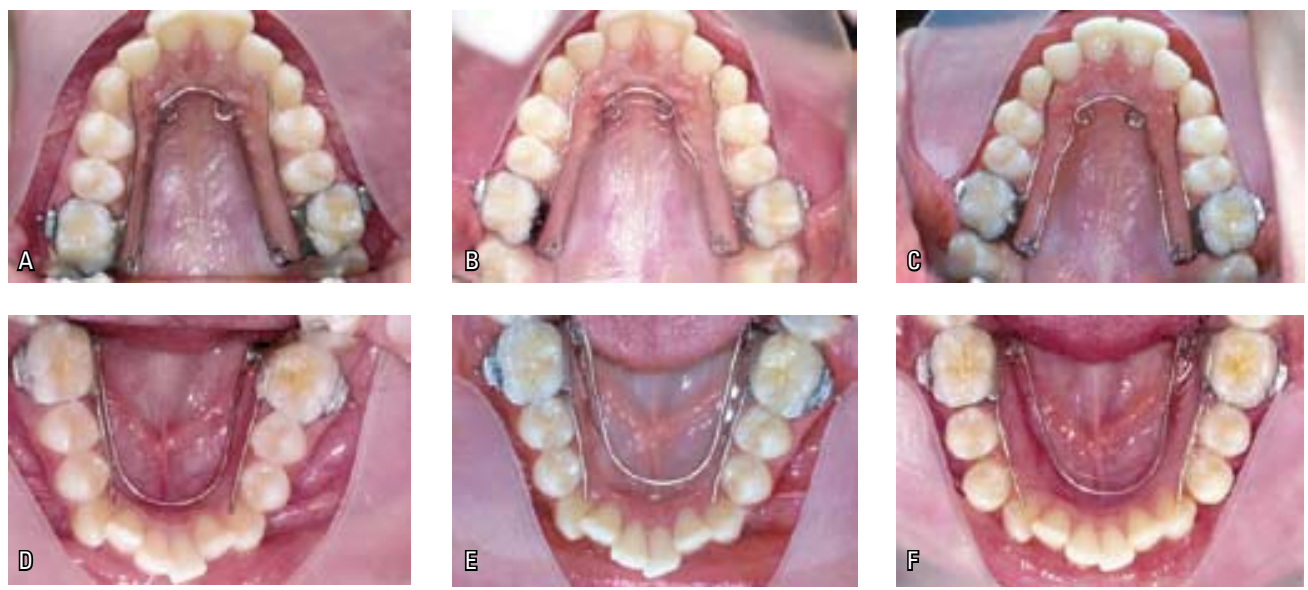

FIGURA 33 - A, B, C) mostram o desenvolvimento do arco superior diante da ativação do quadrihélice. D, E, F) mostram a melhora do grau de apinhamento do arco inferior bem como a abertura de espaços nos setores látero-posteriores.
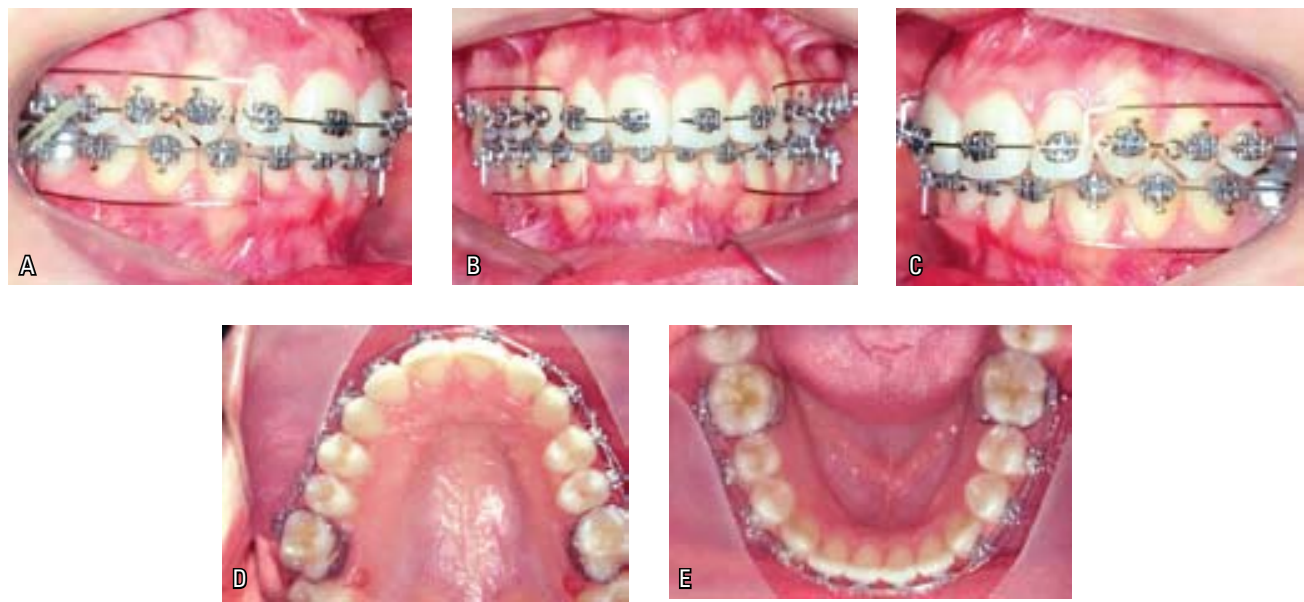

FIGURA 34 - Arco utilidade superior, para realizar a intrusão dos incisivos, e mecânica overlay no arco inferior.
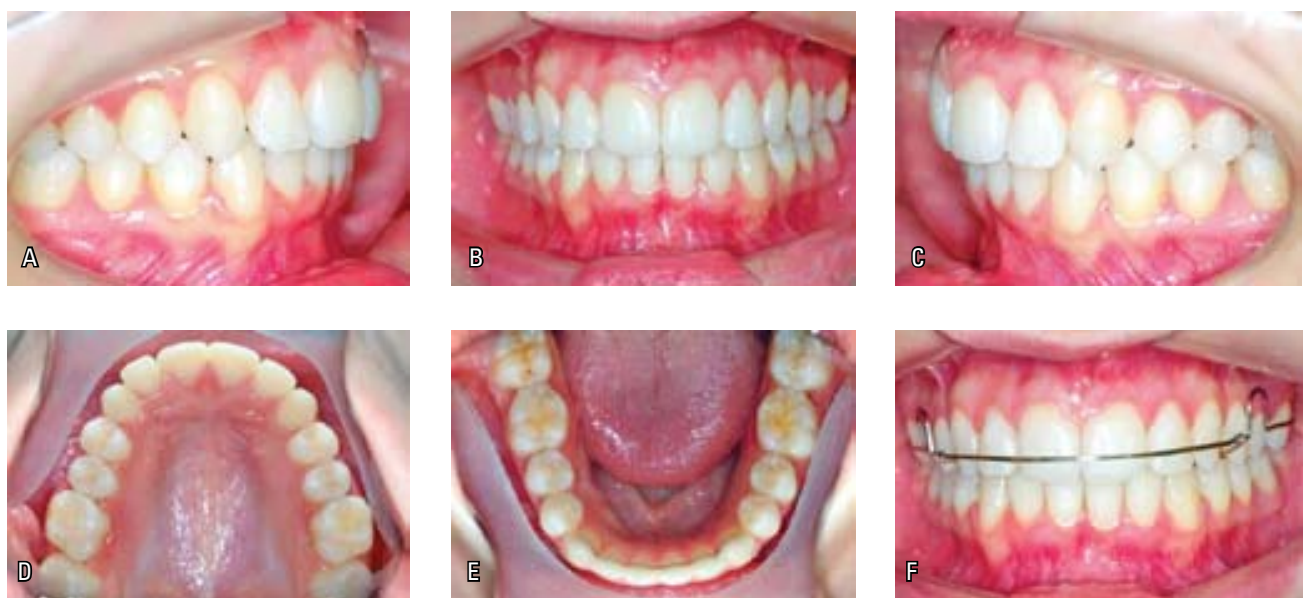

FIGURA 35 - Oclusão final. Observe a correção do apinhamento, o restabelecimento transversal adequado dos arcos, assim como 0 acerto da linha média. Barra lingual colada em todos os dentes ântero-inferiores ${ }^{4,23}$. 

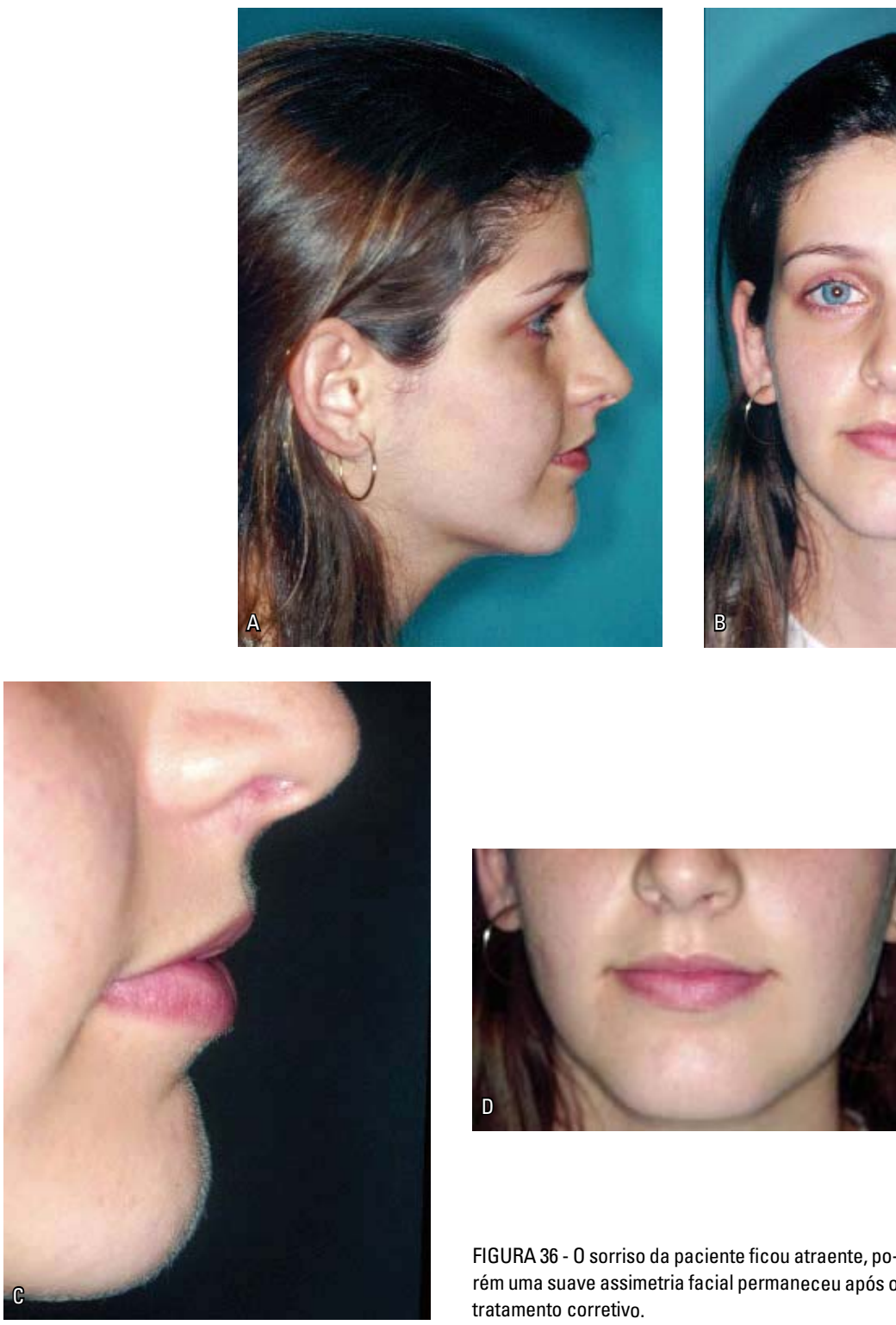

FIGURA 36 - 0 sorriso da paciente ficou atraente, porém uma suave assimetria facial permaneceu após o tratamento corretivo.
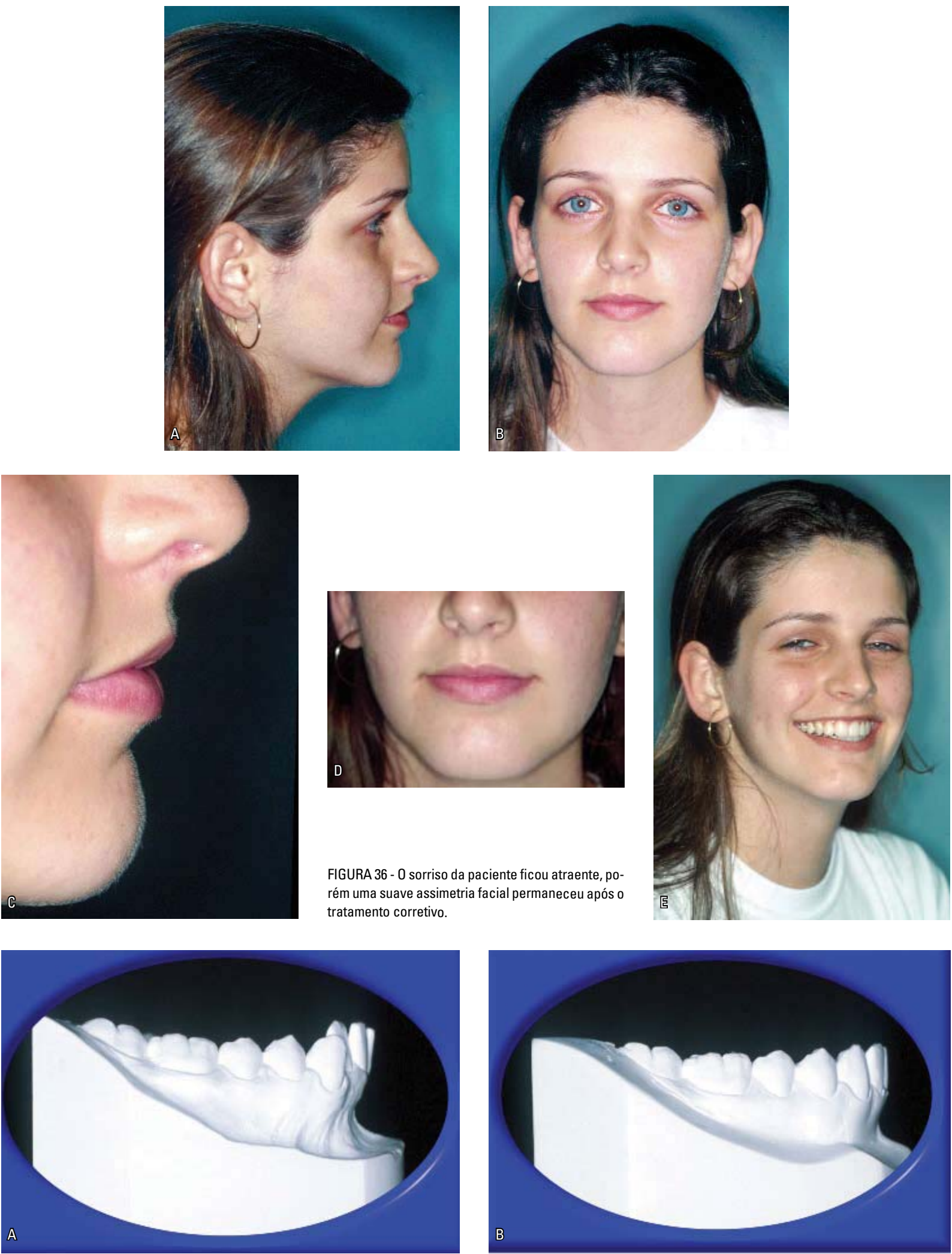

FIGURA 37 - Observe o nivelamento da curva de Spee por meio da intrusão dos incisivos inferiores ${ }^{5,15}$. 


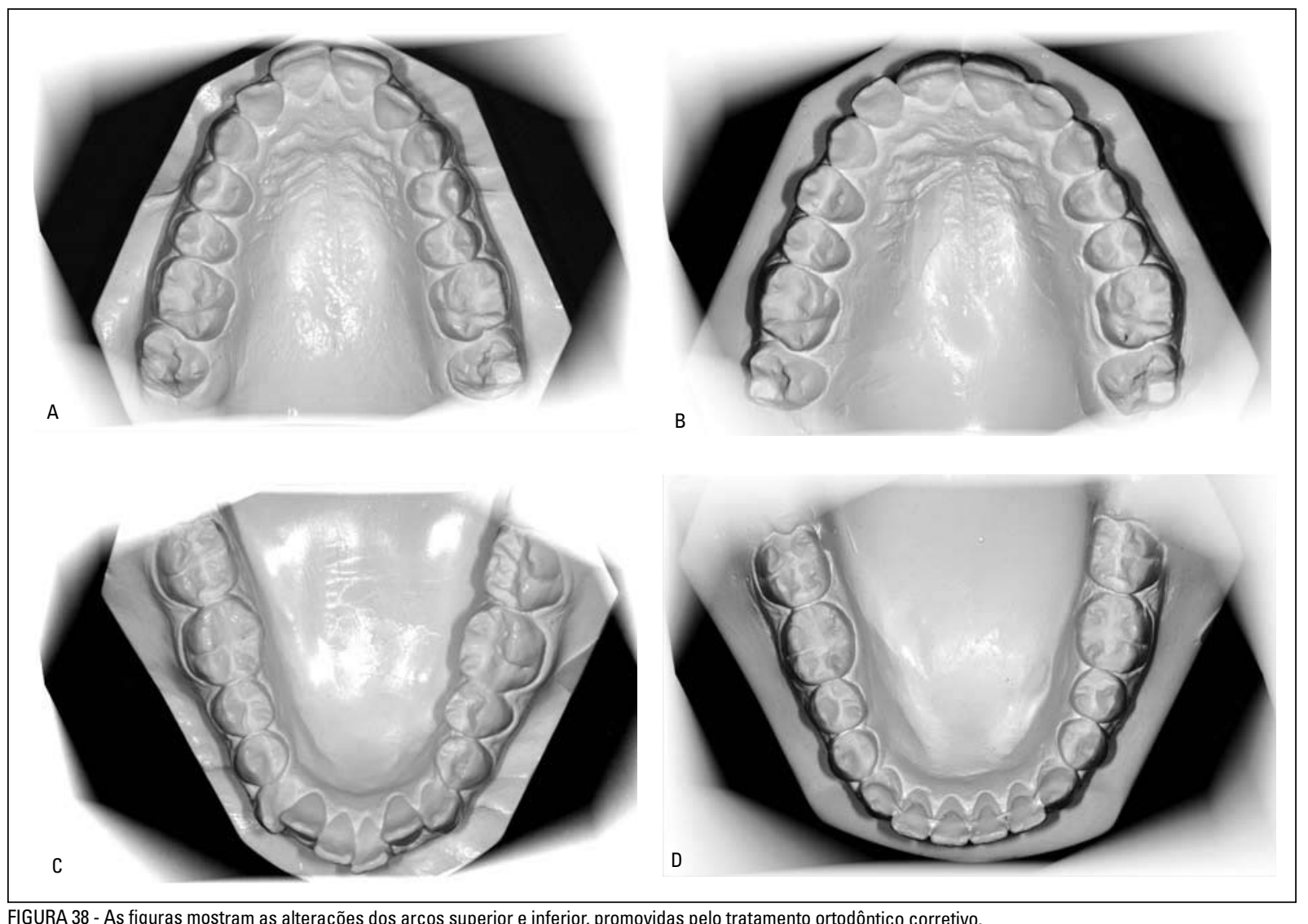

FIGURA 38 - As figuras mostram as alterações dos arcos superior e inferior, promovidas pelo tratamento ortodôntico corretivo.

Todas as ativações realizadas no aparelho bihélice foram feitas fora da cavidade bucal, enquanto as ativações do quadrihélice foram feitas intrabucalmente pelo emprego do alicate de três pontas.

Se analisarmos matematicamente as alterações ocorridas nos arcos superior e inferior mostradas na tabela 2, fica evidente que o perímetro do arco inferior, o qual é crítico em relação ao ganho de espaço, teve um aumento expressivo de pelo menos $7 \mathrm{~mm}$. Houve um aumento de $5 \mathrm{~mm}$ na distância molar, o que contribuiu para originar um acréscimo de $1 \mathrm{~mm}$ no perímetro do arco. Já as distâncias transversais (inicial e final) entre os segundos pré-molares e os primeiros pré-molares tiveram um aumento semelhante, ou seja, de $5,5 \mathrm{~mm}$. Isso levou o arco inferior a sofrer um incremento em seu perímetro de
Tabela 2 - Alterações transversais ocorridas no arco inferior pelo uso do aparelho bihélice em conjunto com o aparelho quadrihélice no arco superior.

\begin{tabular}{cccc}
\hline $\begin{array}{c}\text { Distância } \\
\text { inter-dental }\end{array}$ & $\begin{array}{c}\text { Valores norma- } \\
\text { tivos }\end{array}$ & $\begin{array}{c}\text { Valores } \\
\text { iniciais }\end{array}$ & Valores finais \\
$\begin{array}{c}\text { Primeiros } \\
\text { molares }\end{array}$ & $55 \mathrm{~mm} \pm 2$ & $49 \mathrm{~mm}$ & $54 \mathrm{~mm}$ \\
$\begin{array}{c}\text { Segundos } \\
\text { pré-molares }\end{array}$ & $46 \mathrm{~mm} \pm 2,4$ & $42 \mathrm{~mm}$ & $47,5 \mathrm{~mm}$ \\
$\begin{array}{c}\text { Primeiros } \\
\text { pré-molares } \\
\text { Caninos }\end{array}$ & $40 \mathrm{~mm} \pm 2$ & $36 \mathrm{~mm}$ & $41,5 \mathrm{~mm}$ \\
\hline
\end{tabular}

aproximadamente $4 \mathrm{~mm}$. O aumento transversal da distância entre os caninos forneceu mais $2,5 \mathrm{~mm}$ de ganho de espaço no arco inferior. Portanto, a soma dos resultados envolvendo as diferenças entre distâncias transversais (inicial e final) dos dentes citados na tabela 2 sugere um aumento de $7 \mathrm{~mm}$ de espaço no arco inferior. 


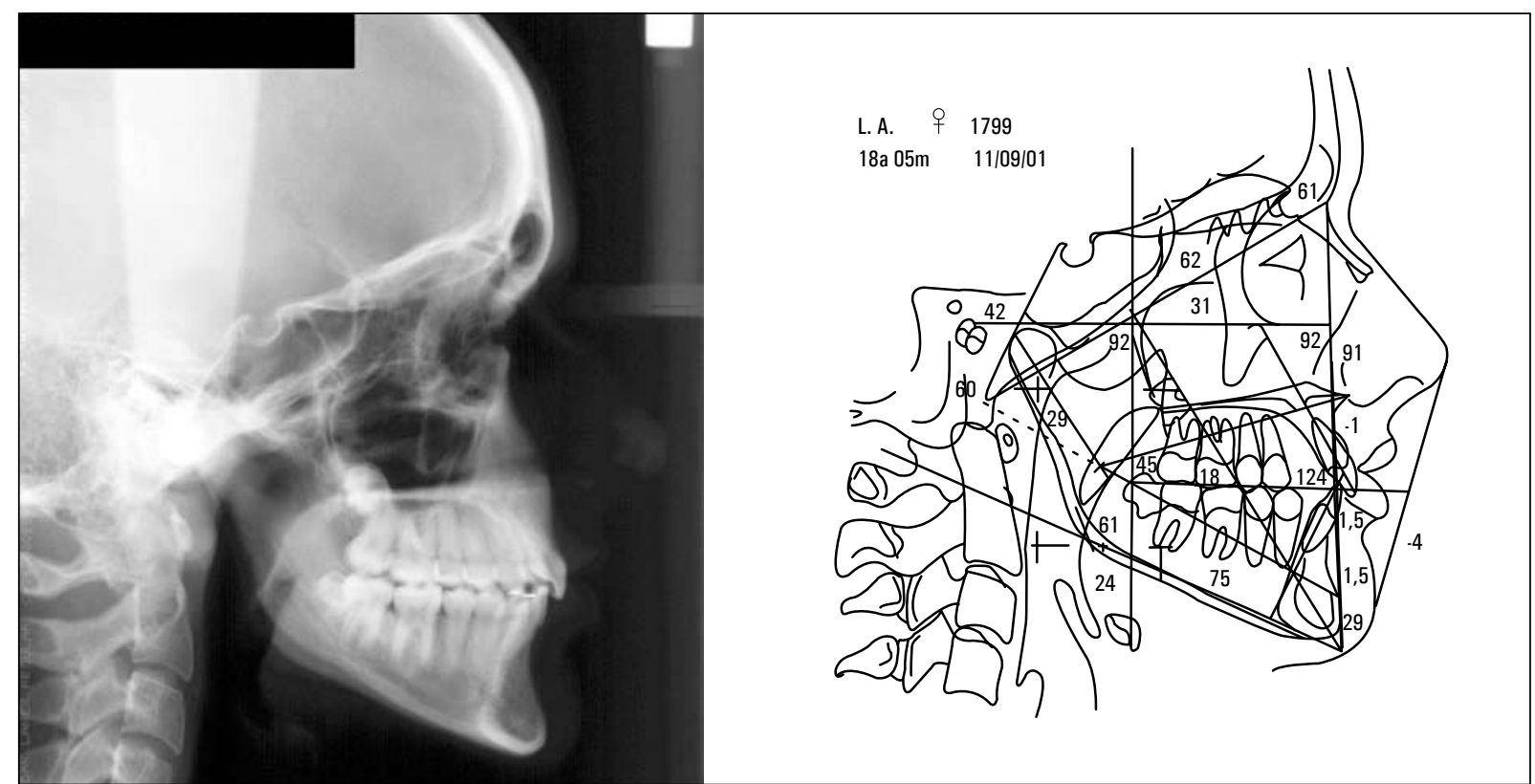

FIGURA 39 - Telerradiografia de norma lateral e cefalograma de Ricketts apresentando os resultados finais do tratamento.
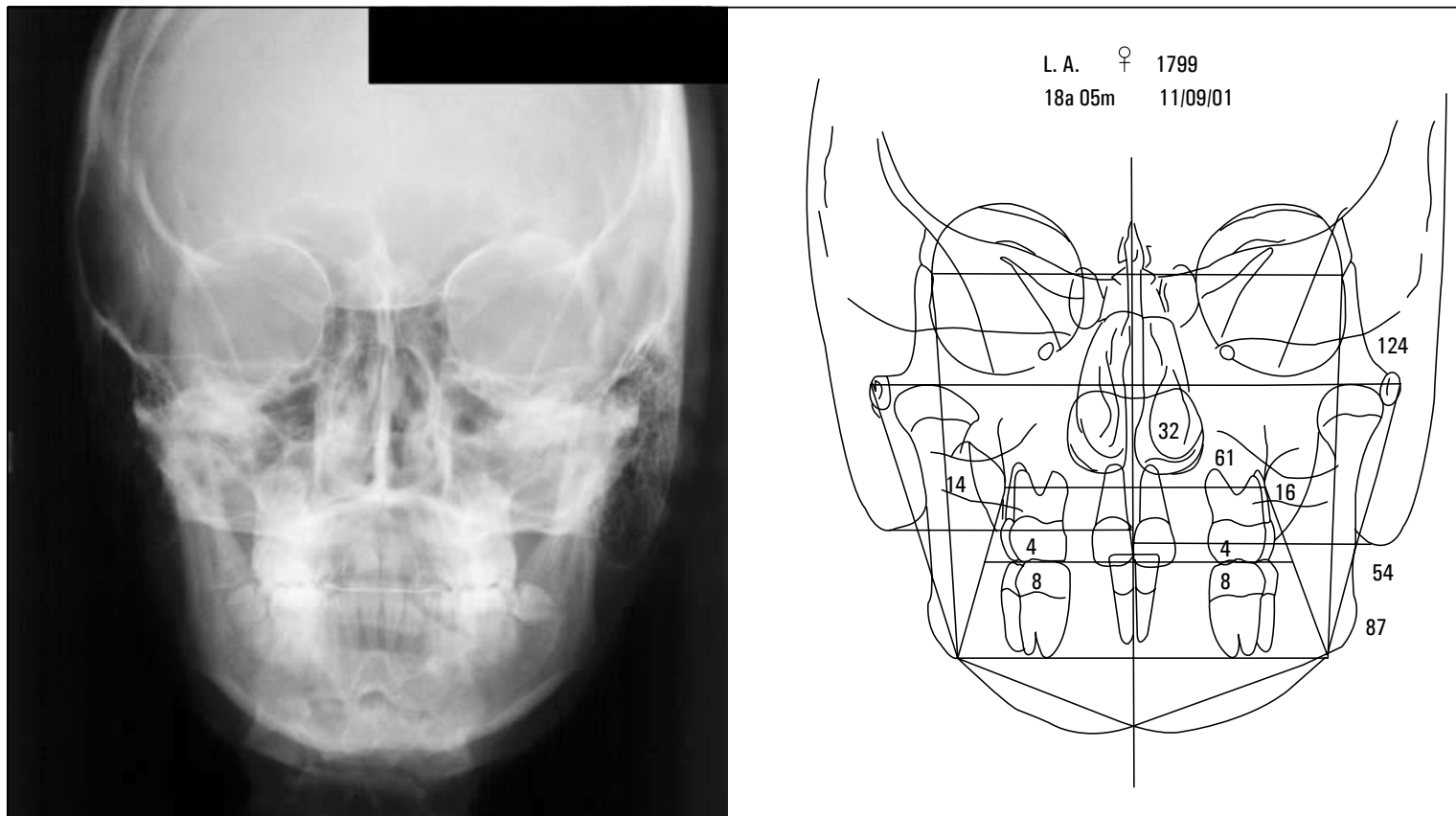

FIGURA 40 - Telerradiografia de norma frontal e cefalograma de Ricketts apresentando os resultados finais do tratamento. 


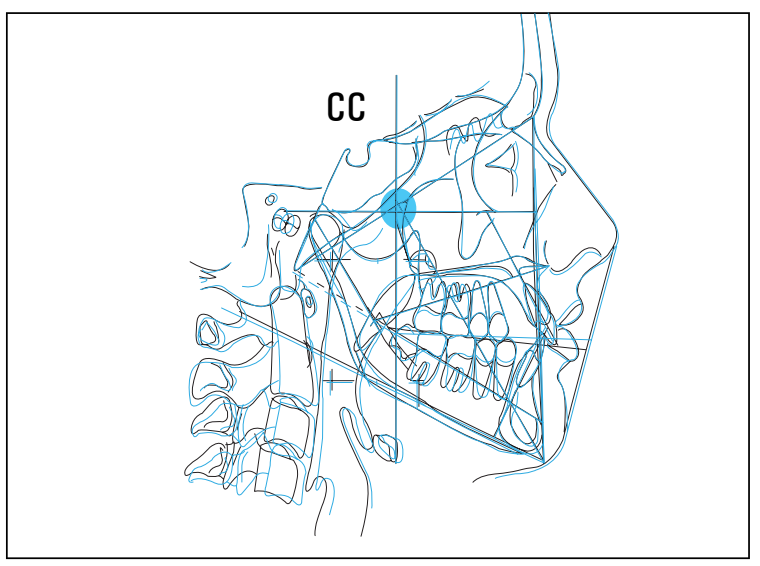

FIGURA 41 - A sobreposição no centro do crânio (CC) mostra que não ocorreu rotação horária da mandíbula, como muitas vezes é esperado quando se adotam esses protocolos de tratamentos.

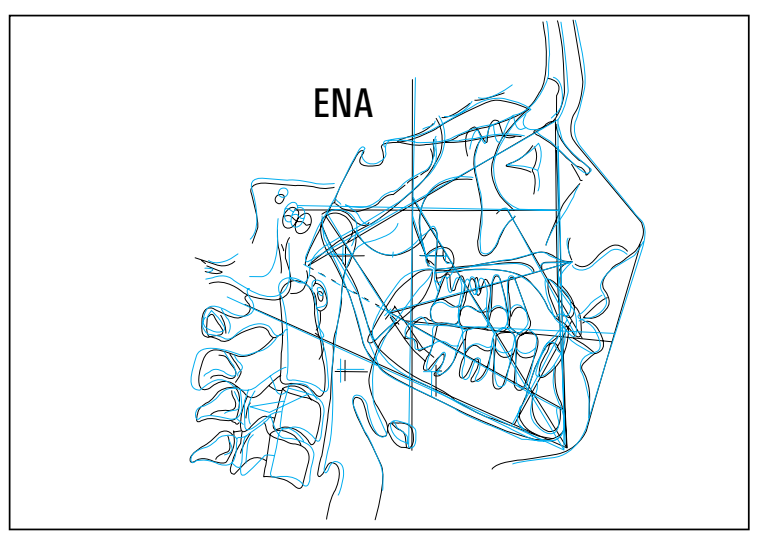

FIGURA 43 - A sobreposição na espinha nasal anterior (ENA) mostra a ancoragem máxima nos molares superiores, assim como a intrusão dos incisivos superiores.

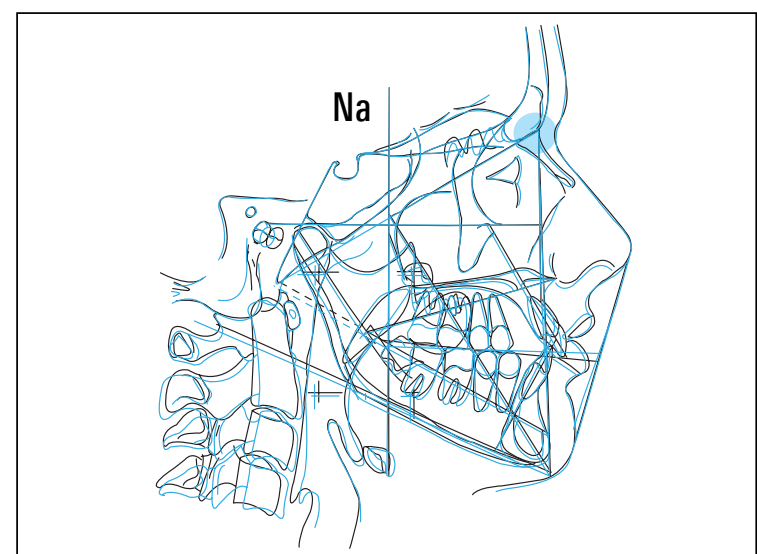

FIGURA 42 - A sobreposição em násio (Na) mostra um discreto aumento do ângulo básio - násio - ponto $A$.

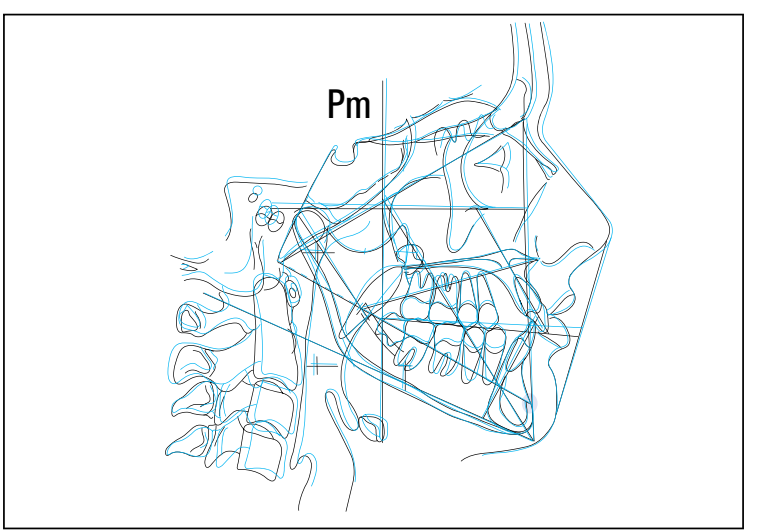

FIGURA 44 - Na sobreposição da protuberância do mento (Pm), se pode observar a alteração do plano oclusal funcional de Ricketts, a verticalização dos incisivos inferiores e a nova posição do eixo condilar.

O aparelho quadrihélice atendeu às necessidades da quarta área de sobreposição do VTO, no que concerne aos molares superiores, e o aparelho bihélice foi eficaz em restabelecer a dimensão transversal adequada ao arco inferior. $\mathrm{O}$ arco utilidade de Ricketts também foi muito efetivo em atender necessidades impostas pela terceira área do VTO, no que diz respeito à ancoragem cortical dos molares inferiores, ao controle do plano oclusal funcional e à verticalização dos incisivos inferiores. Desse modo, o paradigma criado em relação à abertura do eixo facial de Ricketts em $1^{\circ}$, com recupera- 
ção de $0,50^{\circ}$, pelo uso do aparelho quadrihélice, deixa de ter validade quando se emprega a ancoragem cortical nos molares inferiores. A alteração favorável que ocorre no plano oclusal funcional favorece a verticalização dos incisivos inferiores.

Outra indicação de uso do aparelho quadrihélice na terapia bioprogressiva é como auxiliar de ancoragem. Nesse caso, ele pode ser usado com as suas hastes laterais palatinas encurtadas. As ativações necessárias para promover o com- prometimento da lâmina cortical são a rotação e a expansão molar. Desse modo, podemos preparar adequadamente os molares superiores para receber as molas de retração dos caninos, as quais, quando ativadas corretamente, irão liberar forças de no máximo 0,8 newtons, sendo assim, adequadas para a retração dos caninos superiores sem comprometer o sistema de ancoragem. Agindo dessa maneira, estamos preservando a ancoragem posterior sem a necessidade do botão palatino e da ancoragem extrabucal.
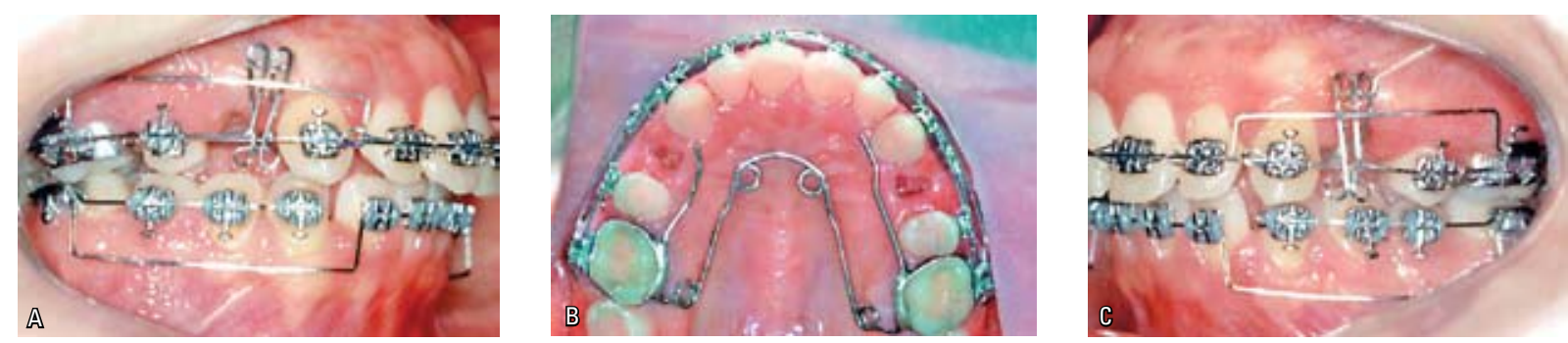

FIGURA 45 - 0 aparelho quadrihélice como um acessório para estabelecer ancoragem. Sistema de retração dos caninos com a colocação de um fio guia (modificação do autor).

Há também várias modificações úteis que podem ser feitas no aparelho quadrihélice básico. A colocação de fio de seção 0,045 " no tubo para a ancoragem extrabucal cervical permite que o aparelho possa ser usado em conjunto com uma máscara de protração para avançar a maxila.
O setor anterior do quadrihélice pode ser modificado para controlar o hábito de chupar o dedo e o de interpor a língua entre os dentes, por meio da colocação de uma grade (Fig. 48). Isso faz com que haja um restabelecimento do desenvolvimento dos processos alveolares e dos dentes nas regiões
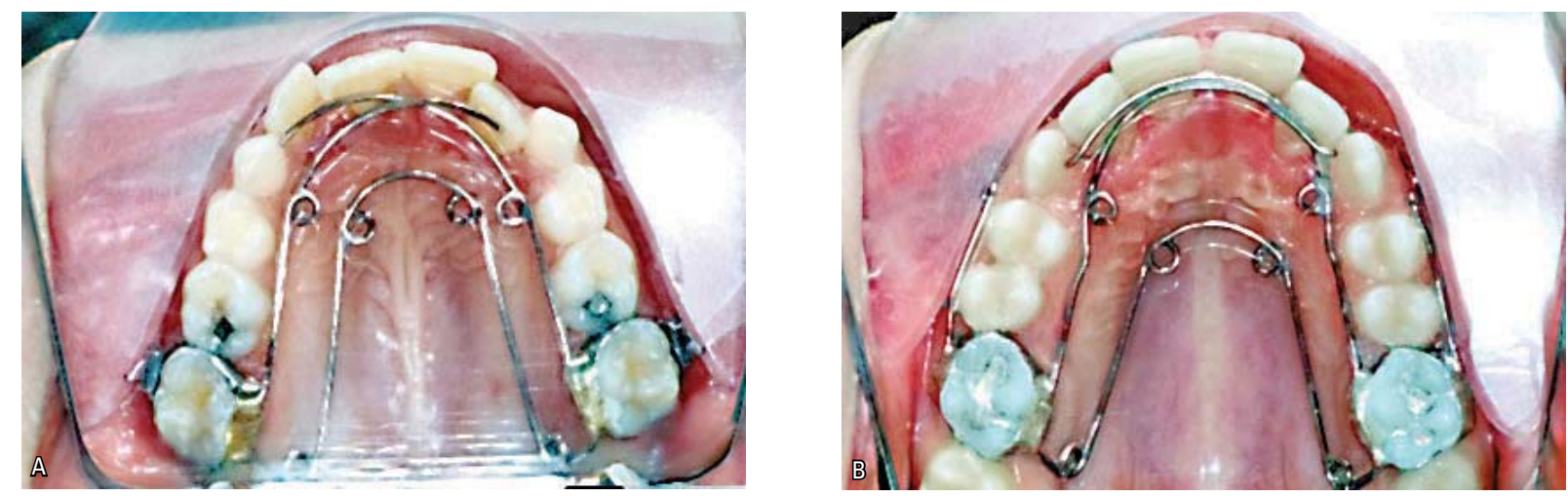

FIGURA 46 - A) Hexahélice antes da ativação; B) após a ativação. Observe o aumento da profundidade de arco pela vestibularização dos incisivos. 

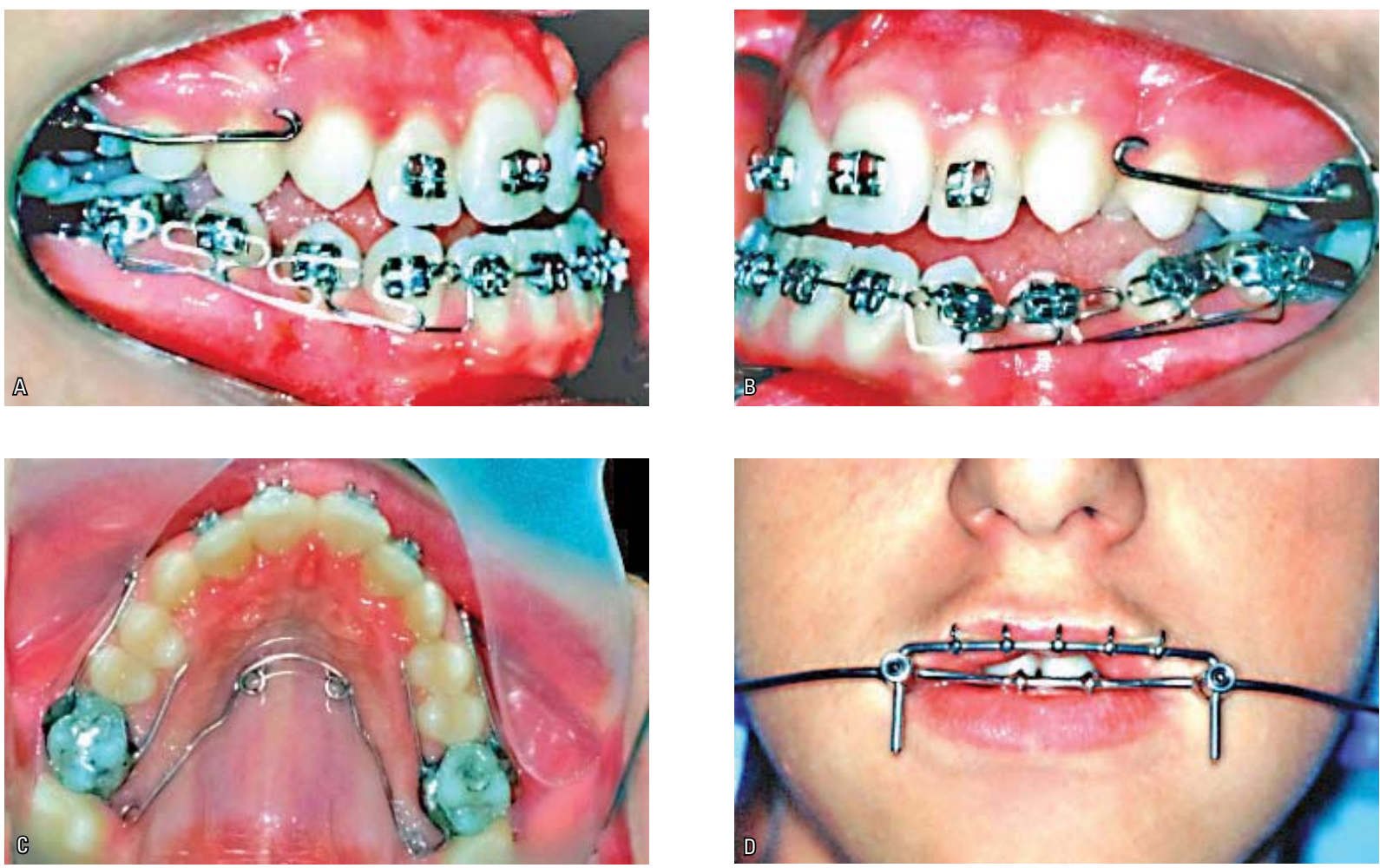

FIGURA 47 - A, B, C) mostram a adaptação de um semi-arco para uso dos elásticos do aparelho extrabucal. D) pode-se ver o aparelho extrabucal de Batista1.

anteriores. Uma consideração relevante é que devemos confeccionar o setor anterior do aparelho quadrihélice em forma de arco e localizá-lo sempre que possivel sobre a primeira rugosidade do palato, ou seja, muito próximo da face palatina dos incisivos superiores. Assim, estamos viabilizando os movimentos peristálticos da língua.

Para confeccionar a grade anterior, devemos
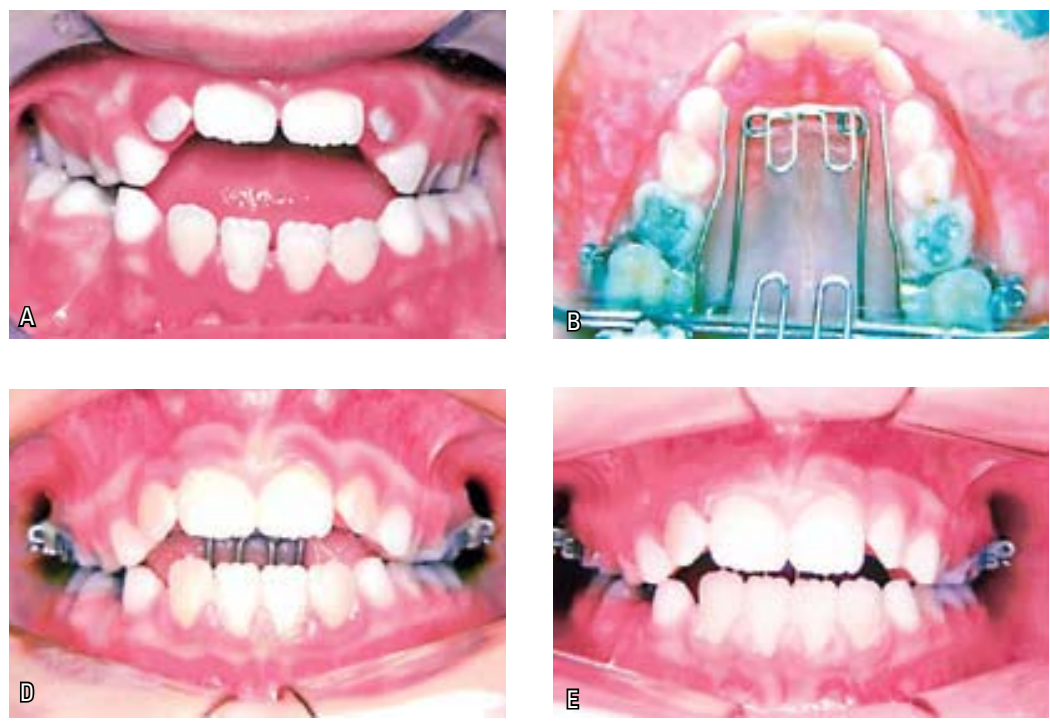
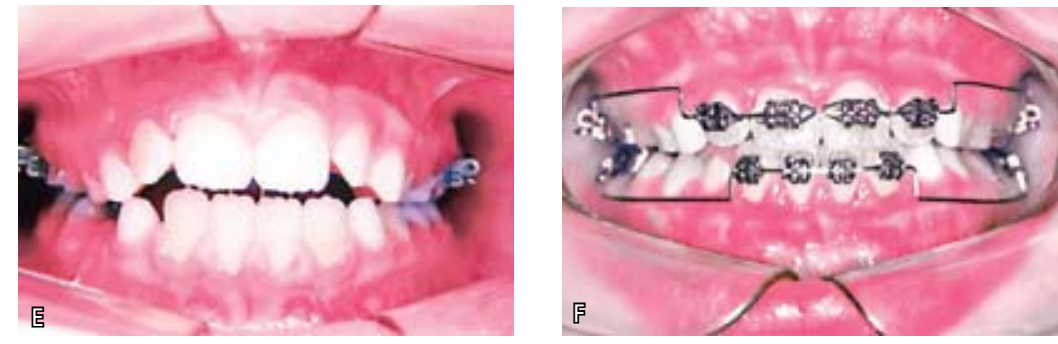

FIGURA 48 - A seqüência de fotos ilustra os benefícios do aparelho quadrihélice na intervenção precoce da mordida aberta e cruzada bilateral. 
levar em consideração o arco de crescimento mandibular. O padrão de crescimento vertical não permite nenhuma interferência nos molares superiores que os induza a sofrerem extrusão descontrolada gerando uma situação de fulcro molar. Caso isso ocorra, haverá um agravamento ainda maior da altura facial inferior ${ }^{19}$, que já se encontra alterada em sua norma devido à direção vertical de crescimento da mandíbula. Associado à direção de crescimento vertical, o paciente com essas características geralmente possui o arco mandibular desfavorável, mostrando a ineficiência muscular no controle rotacional da mandíbula. Devido a isso, foi colocado um apoio de acrílico no setor anterior do aparelho quadrihélice para dar suporte à grade e, assim, evitar qualquer movimento de báscula sobre os molares pela pressão exercida pela língua sobre o impedidor anterior. Outro fato significante é que devemos construir a grade impedidora de hábitos e língua sem o artifício da solda para evitar futuros aborrecimentos com possível quebra do aparelho.
No entanto, após a sobrecorreção da mordida aberta anterior, muitas vezes é necessário realizar uma nova modificação no aparelho quadrihélice com o propósito de melhorar a postura e a tonicidade da língua. Para atingir esses objetivos, são incorporados ao aparelho alguns anéis plásticos (miçangas) no setor anterior. O paciente é orientado a fazer treinamentos diários para rodar esses anéis com a ponta da sua língua. Para isso, ele coloca sobre a língua um pequeno fragmento de alimento (bolacha de água e sal) e dá início aos movimentos peristálticos da língua, que envolvem o processo da deglutição, posicionando-a sobre os anéis. É altamente recomendado fazer o exercício de rotação dos anéis antes de dormir (fase autogênica), porém sem envolver o alimento. Os casos de mordida cruzada posterior e/ou mordida aberta anterior exigem uma atenção especial em relação ao freio sub-lingual, pois não são raras pequenas intervenções nessa estrutura para permitir o posicionamento adequado da língua. Observe o caso clínico abaixo.
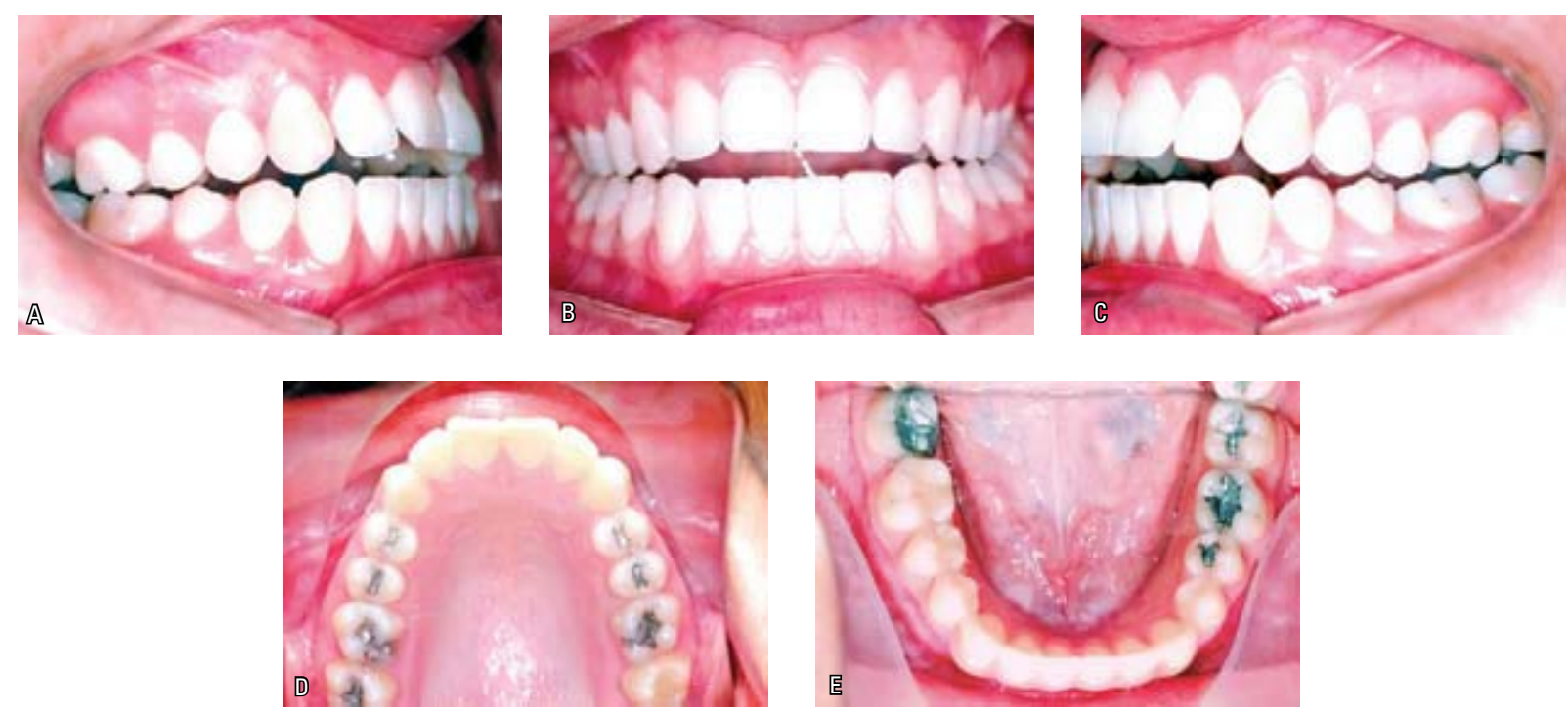

FIGURA 49 - Observe o quadro de mordida aberta anterior, bem como a mordida cruzada posterior. 

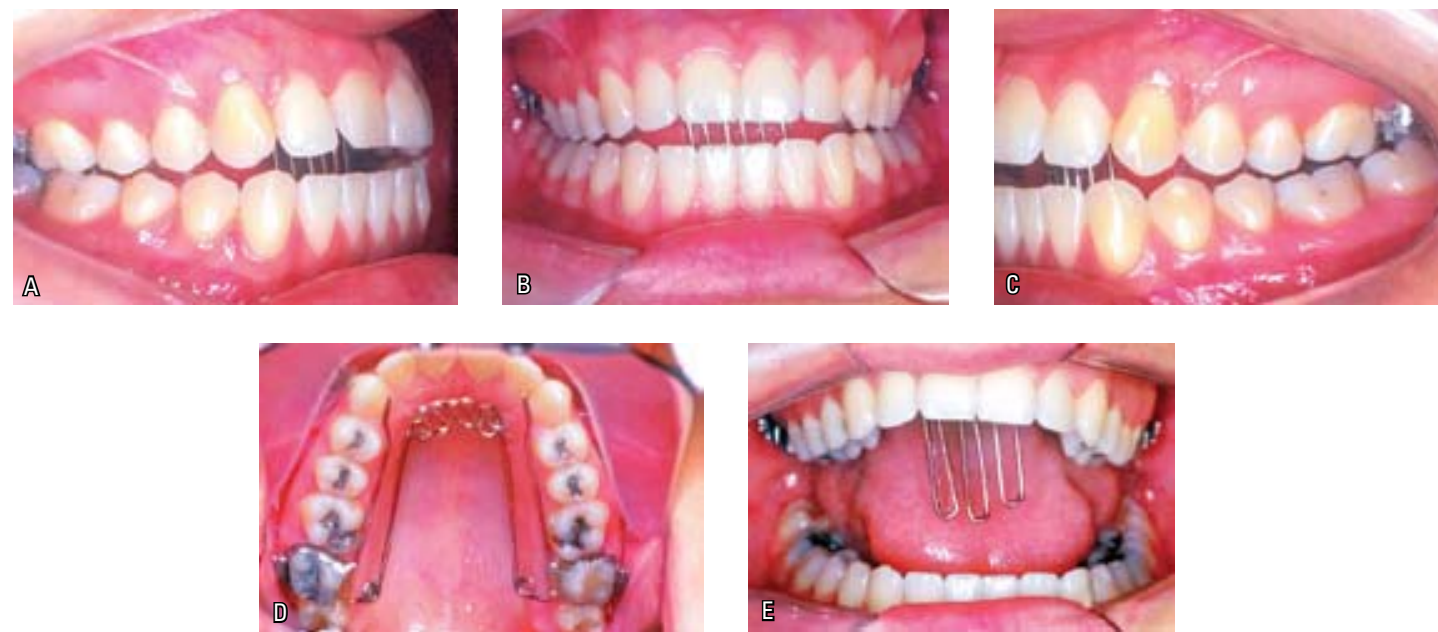

FIGURA 50 - 0 aparelho quadrihélice modificado para impedir a interposição lingual e promover o descruzamento da mordida cruzada posterior.
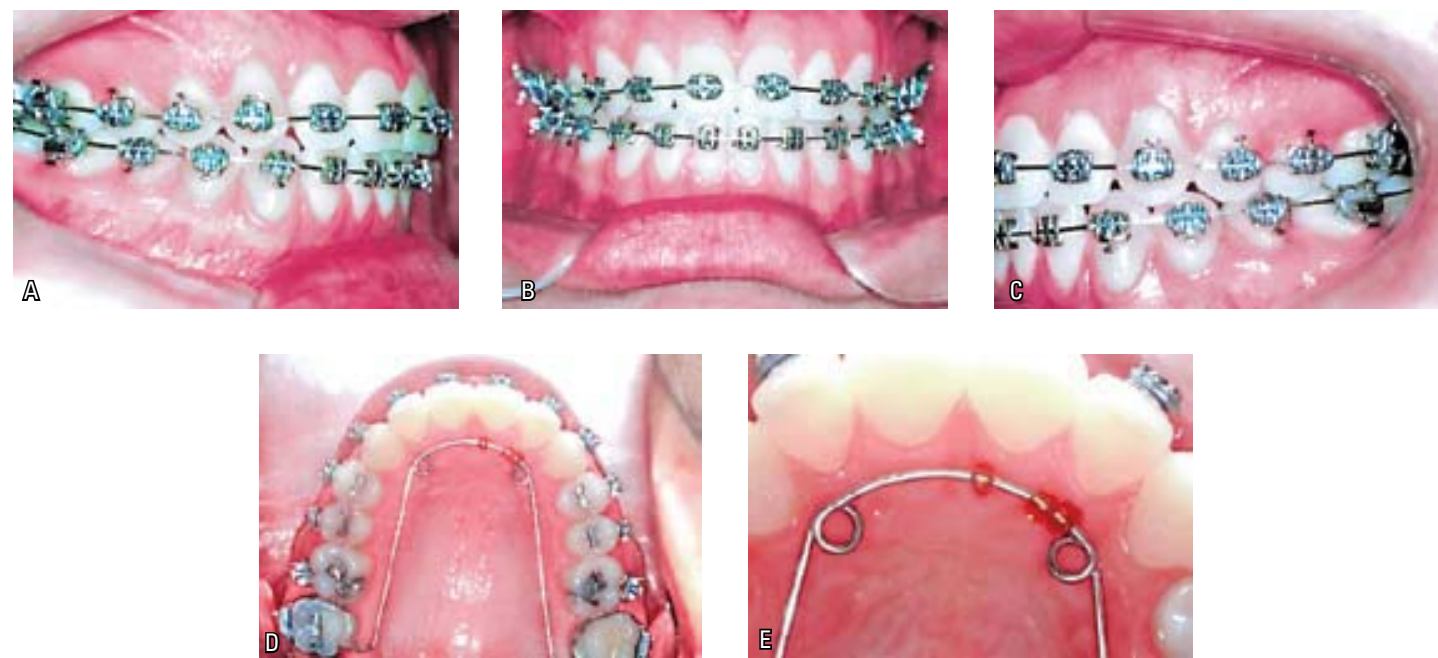

FIGURA 51 - A, B, C) mostram os arcos de finalização. D, E) pode-se visualizar as miçangas no segmento anterior do quadrihélice para restabelecer a postura adequada da língua.
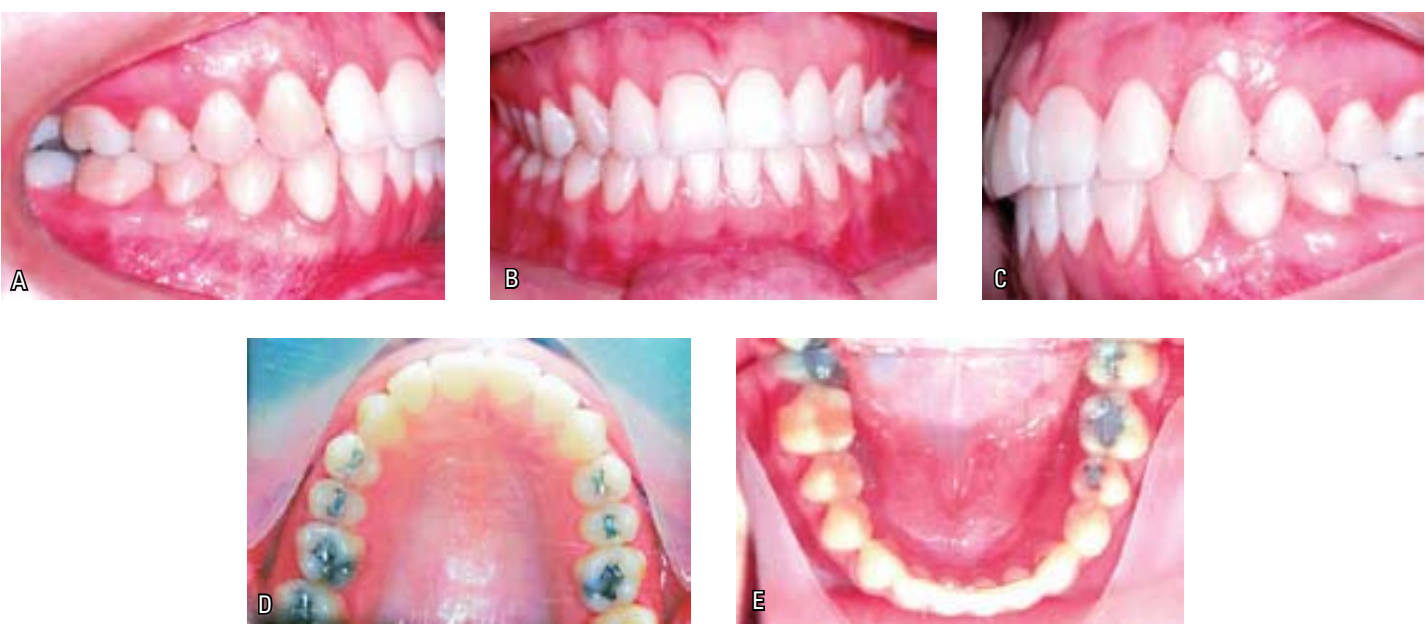

FIGURA 52 - Oclusão final. 
Outra situação muito comum em nossa prática diária são as mordidas cruzadas unilaterais envolvendo todos os dentes do segmento de um arco ou apenas um ou dois dentes. Devemos sempre levar em consideração alguns procedimentos para diferenciar a mordida cruzada bilateral de uma verdadeira mordida cruzada unilateral. O diagnóstico diferencial, nesses casos também requer a análise da cefalometria frontal, com o intuito de avaliar com maior precisão a dimensão das estruturas afetadas. $\mathrm{O}$ procedimento clínico que normalmente adotamos de colocar os dentes anteriores, superiores e inferiores em uma relação de topo-a-topo, para diferenciar a mordida cruzada bilateral da unilateral, serve como uma orientação inicial, porém não devemos estabelecer nenhum diagnóstico conclusivo sem correlatar esse achado com a cefalometria póstero-anterior. Nesses casos, o aparelho quadrihélice é submetido a uma modificação para criar estabilidade (ancoragem) em um lado do arco superior e, ao mesmo tempo, liberar uma pressão adequada nos dentes do lado em que existe uma mordida cruzada unilateral. Observe, nas imagens da figura 53, em que o braço lateral do quadrihélice, pela face palatina dos dentes, estende-se até ao nível do dente canino. Alem disso, é feita uma modificação no desenho original para dar suporte ao material resinoso, colocado nessa região para criar ancoragem e neutralizar a reação da força que é empregada para promover o descruzamento dentário do lado oposto. A ativação inicial recomendada nesses casos não deve ser semelhante àquela que
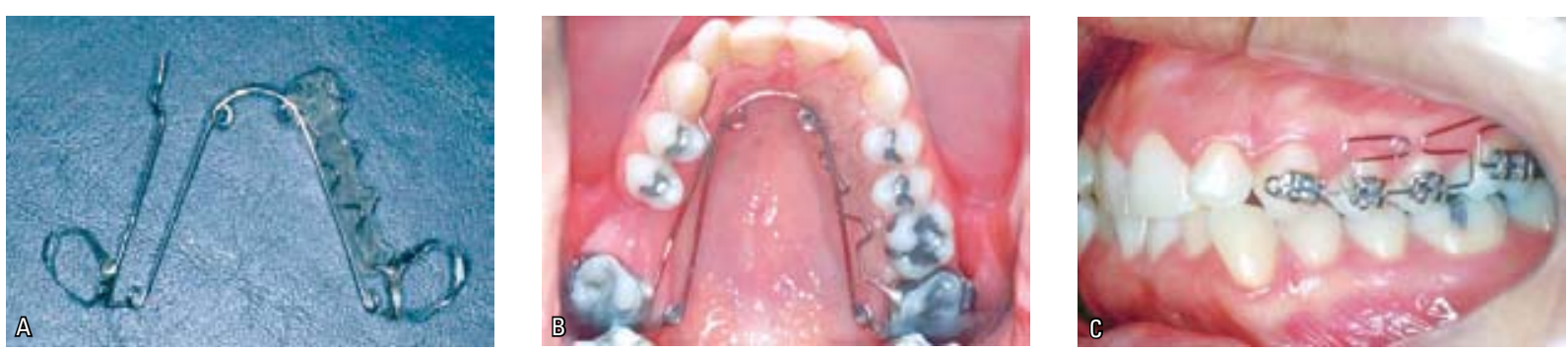

FIGURA 53 - A) pode-se observar o acrílico adaptado na região lateral do aparelho; B) a sua instalação intrabucal; C) o arco seccionado de nivelamento para auxiliar na ancoragem.

realizamos nos casos de mordida cruzada bilateral, mas sim reduzida pela metade, com a finalidade de não comprometer o segmento de ancoragem. Outro procedimento que podemos acrescentar é a colocação de um arco seccionado no setor em que desejamos estabelecer a ancoragem.

Outra modificação que é realizada no aparelho é a diminuição do número de helicóides para promover o descruzamento específico de um determinado dente. Nesse caso, o aparelho é construído com três molas helicoidais; em virtude disso, o seu desenho original sofre uma discreta modificação. Semelhante ao caso de mordida cruzada unilateral, devemos ser criteriosos na ativação desse aparelho modificado, pois o mesmo possui uma quantidade menor de fios em relação ao aparelho original.
Desse modo, ele tem a propriedade de liberar uma pressão maior do que a desejada sobre o dente a ser movimentado. Assim, a ativação inicial não excede 4 milimetros. As ativações subseqüentes, se houver necessidade, têm que obedecer a um intervalo de aproximadamente 40 dias.

Se houver necessidade, o profissional poderá colocar acrílico na região do palato, bem como um arco seccional no setor látero-posterior do lado oposto ao dente a ser movimentado, com o propósito de reforçar a ancoragem. No entanto, não recomendamos a interposição, entre os dentes, de uma placa oclusal com a finalidade de "levantar a mordida" (aumentar o espaço funcional livre), pois esse procedimento leva a mandibula a sofrer rotação horária. Normalmente, o espaço funcional livre já é o suficiente. 

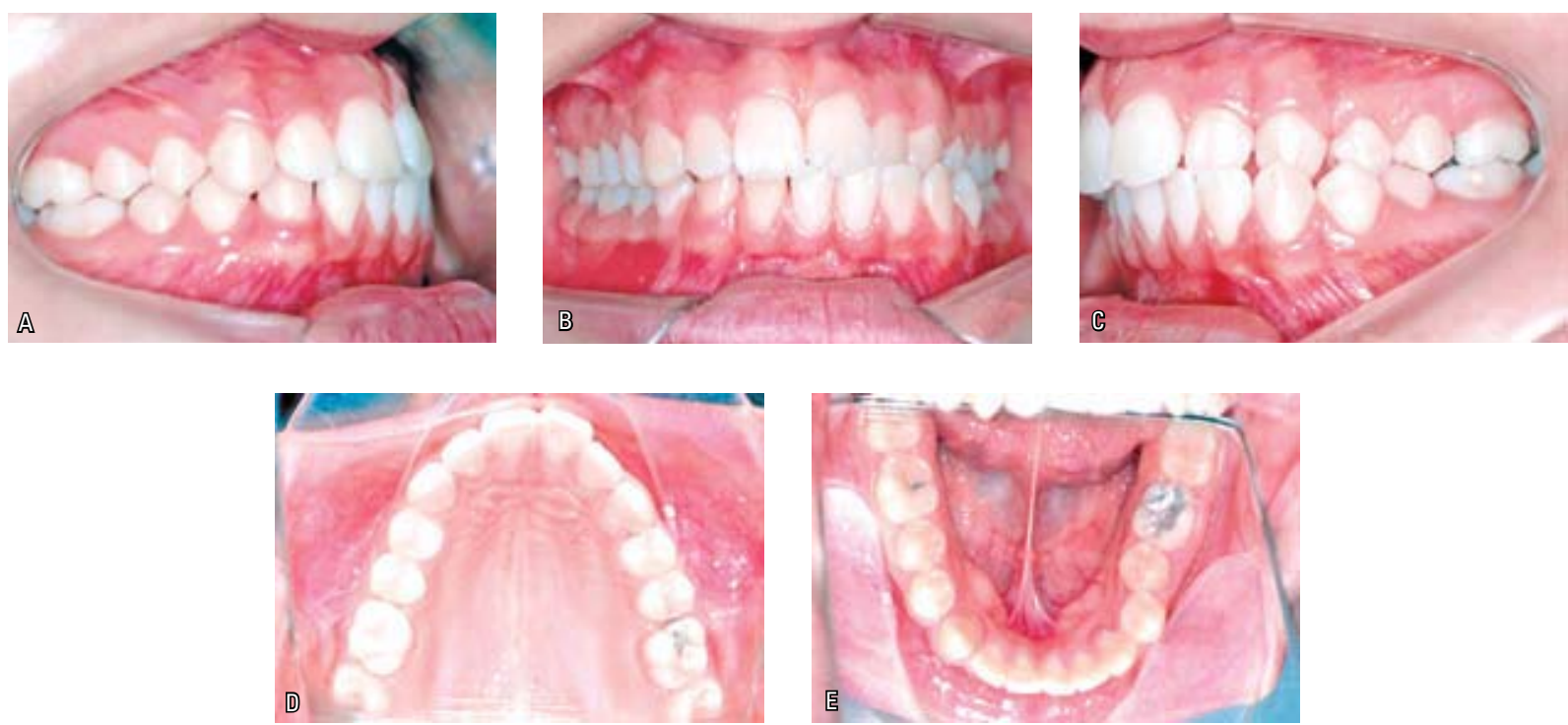

FIGURA 54 - Observe o acentuado desvio da linha média dentária devido ao cruzamento do canino superior direito.
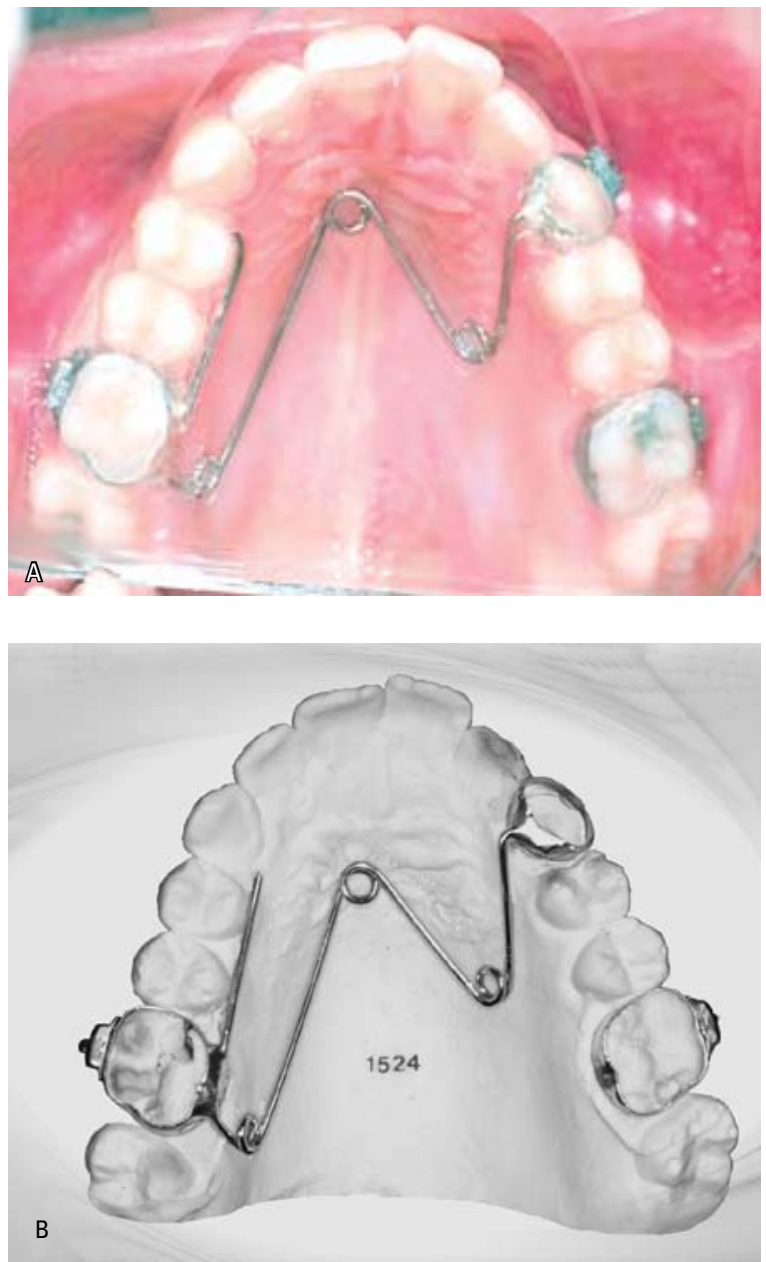

FIGURA 55 - A) o aparelho no modelo de trabalho e B) instalado na cavidade bucal. 

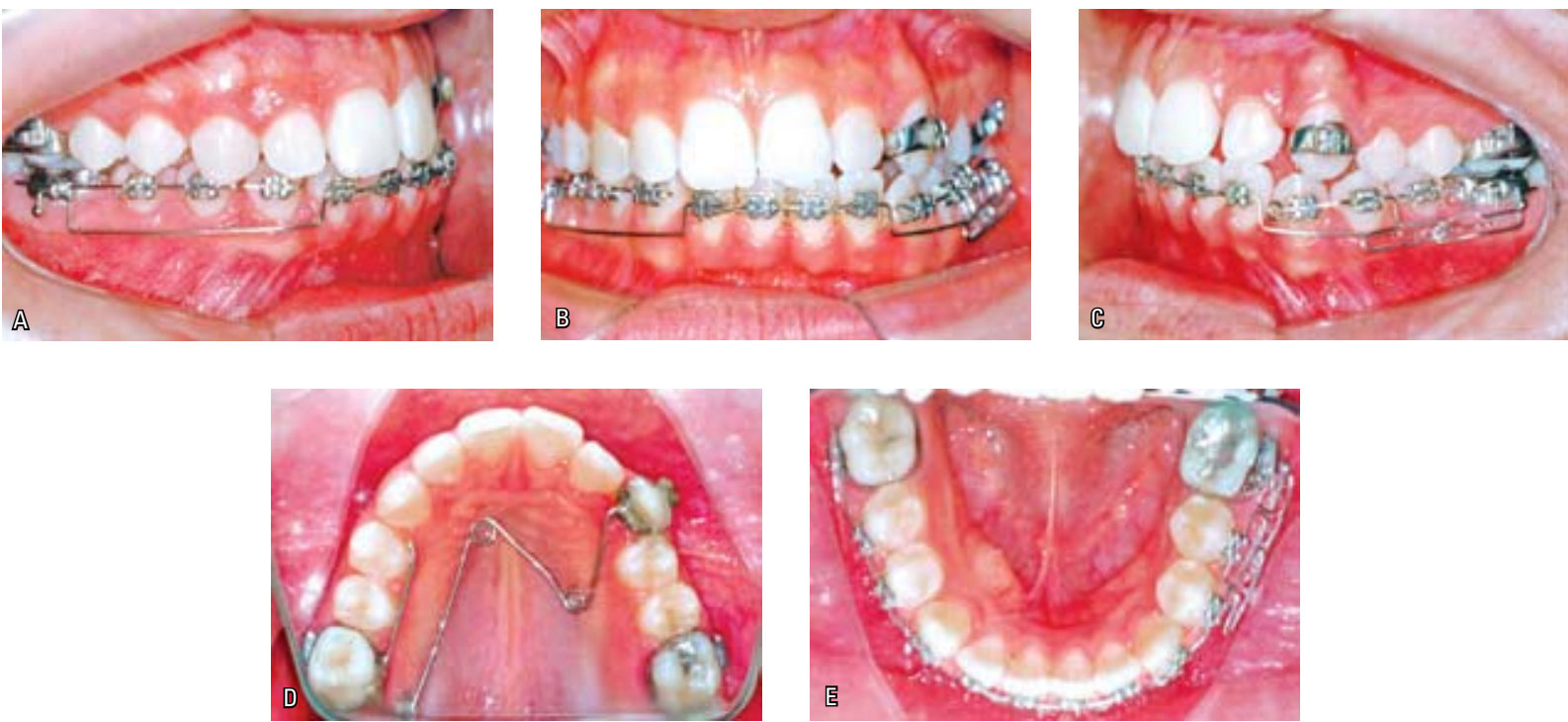

FIGURA 56 - Observe a efetividade do aparelho em promover a correção do descruzamento do canino superior esquerdo.
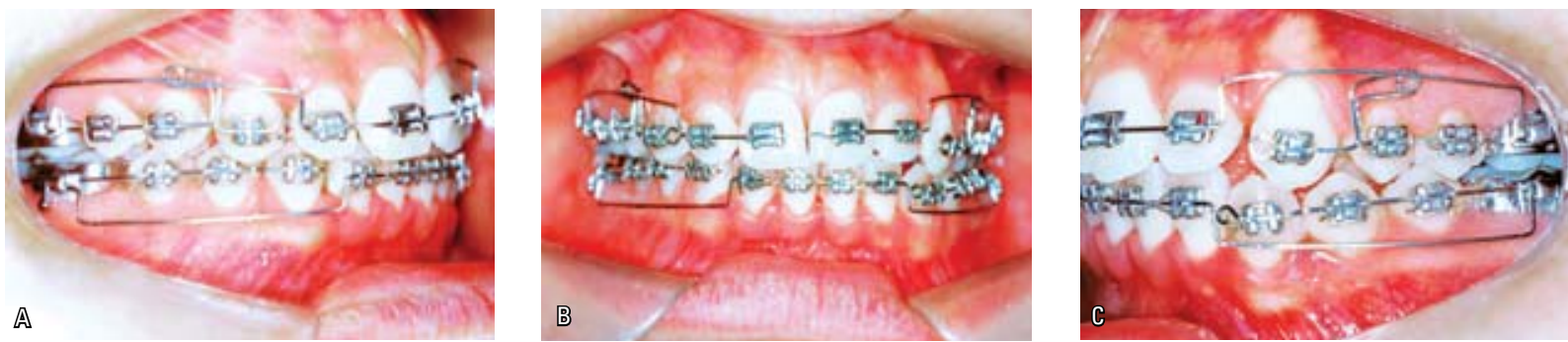

FIGURA 57 - A magnitude do torque foi controlada com a colocação do arco seccionado confeccionado com alça em L.
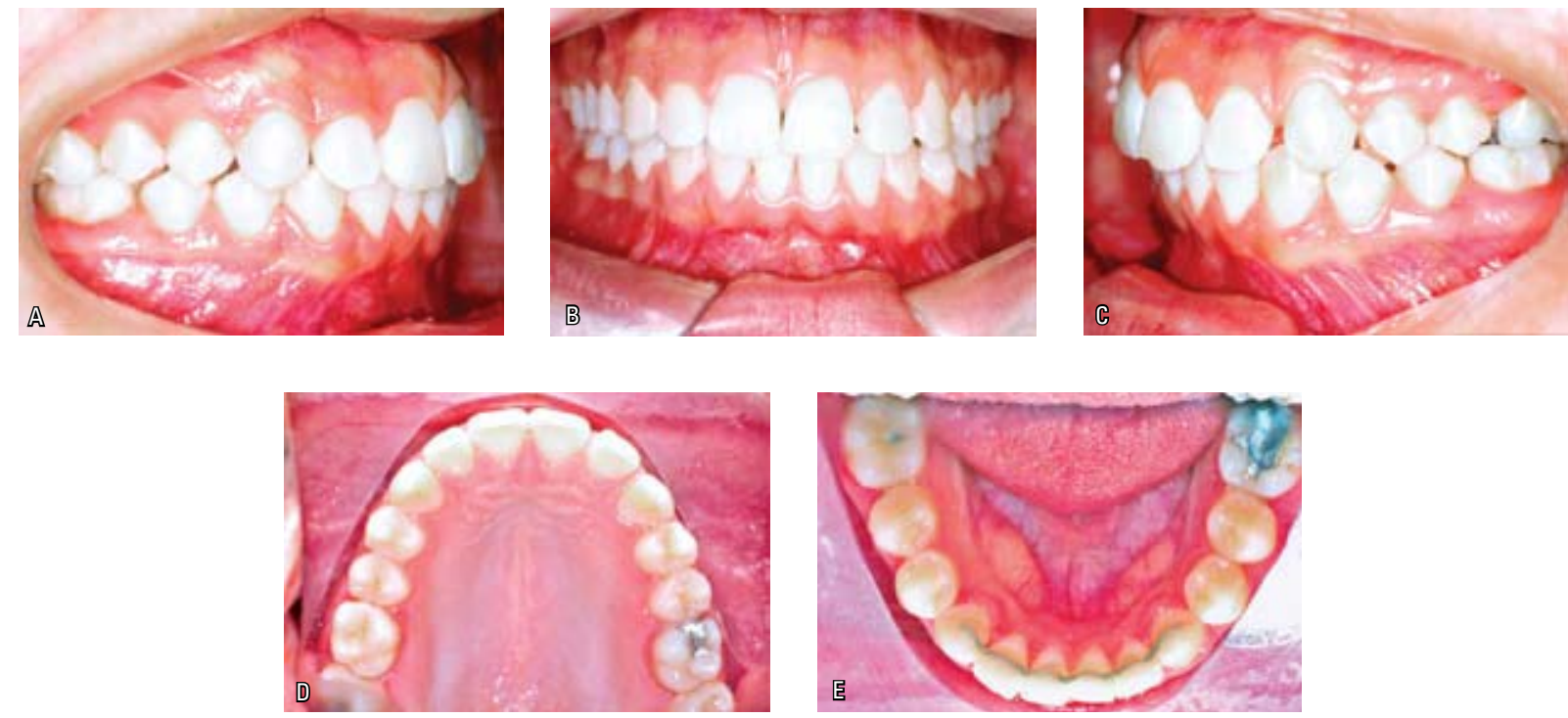

FIGURA 58 - Resultado final. 0 desvio da linha média permaneceu devido ao comprometimento ósseo da mandíbula. 
A quantidade de expansão

O quadrihélice pré-fabricado geralmente apresenta-se em quatro tamanhos diferentes. Ele também pode ser fabricado pelo ortodontista ou técnico especializado. Para isso, utiliza-se um fio de 0,038" redondo, de aço inoxidável, ou um fio elgiloy azul (Rocky Mountain Orthodontics, EUA) com a mesma dimensão. A quantidade de força de expansão do quadrihélice depende da quantidade da expansão antes da cimentação. A relação entre a força de expansão produzida, o tamanho do quadrihélice e a quantidade de ativação é mostrada na tabela 3. O quadrihélice de número 4 , que parece ajustar-se à maioria dos pacientes, libera uma força de expansão de 37 a 42 newtons, quando ativado entre 10 a $15 \mathrm{~mm}$. Um quadrihélice construído com fio de aço, sem tratamento térmico, libera uma força semelhante ao aparelho construído com fio elgiloy azu1 ${ }^{2,21}$.

Um procedimento muito usual é expandir o aparelho quadrihélice de forma que as bandas fi-

Tabela 3 - Forças desenvolvidas pela ativação do Quadrihélice.

\begin{tabular}{llll}
\hline & $5 \mathrm{~mm}$ & $10 \mathrm{~mm}$ & $15 \mathrm{~mm}$ \\
Tamanho $^{\circ} \mathbf{1}$ & $37 \mathrm{~N}$ & $72 \mathrm{~N}$ & \\
Tamanho $^{\circ} \mathbf{2}$ & $35 \mathrm{~N}$ & $49 \mathrm{~N}$ & \\
Tamanho $^{\circ} 3$ & $31 \mathrm{~N}$ & $44 \mathrm{~N}$ & $48 \mathrm{~N}$ \\
Tamanho $^{\circ} 4$ & $26 \mathrm{~N}$ & $37 \mathrm{~N}$ & $42 \mathrm{~N}$ \\
\hline
\end{tabular}

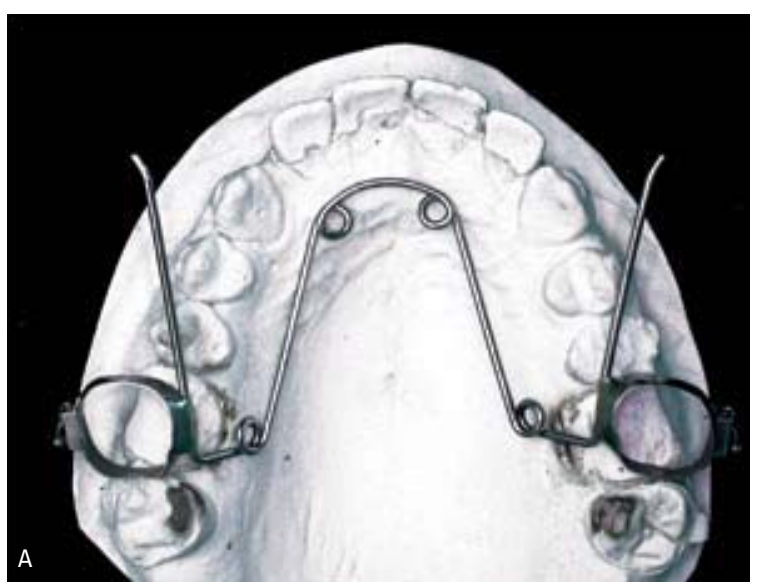

FIGURA 59 - Ativação que antecede a cimentação do aparelho. quem na metade das coroas dos molares antes da cimentação, ou seja, quando uma banda estiver encaixada em um dos molares, a banda do lado oposto do aparelho deve ficar com a sua face palatina tocando a face vestibular do molar do outro lado, como é mostrado na figura 59.

\section{CONCLUSÃO}

O sucesso no tratamento das mordidas cruzadas posteriores, bem como das discrepâncias transversais dos arcos dentários, depende da competência do profissional em diagnosticar corretamente essas manifestações, como também em indicar os aparelhos adequados. Dentre os inúmeros aparelhos utilizados, o quadrihélice pode ser uma alternativa eficiente no tratamento das discrepâncias transversais (unilateral ou bilateral), atuando tanto no reposicionamento dentário quanto no redirecionamento do crescimento mandibular, desde que seja empregada, juntamente com esse protocolo de tratamento, a ancoragem cortical nos molares inferiores. O quadrihélice mostra ser um instrumento valioso no restabelecimento da forma do arco superior, contribuindo, desse modo, para a melhora da função (devido às várias formas de construção), bem como da fisiologia respiratória. Além disso, ele auxilia na mecânica imposta ao arco inferior, no que diz respeito ao tratamento transversal dos

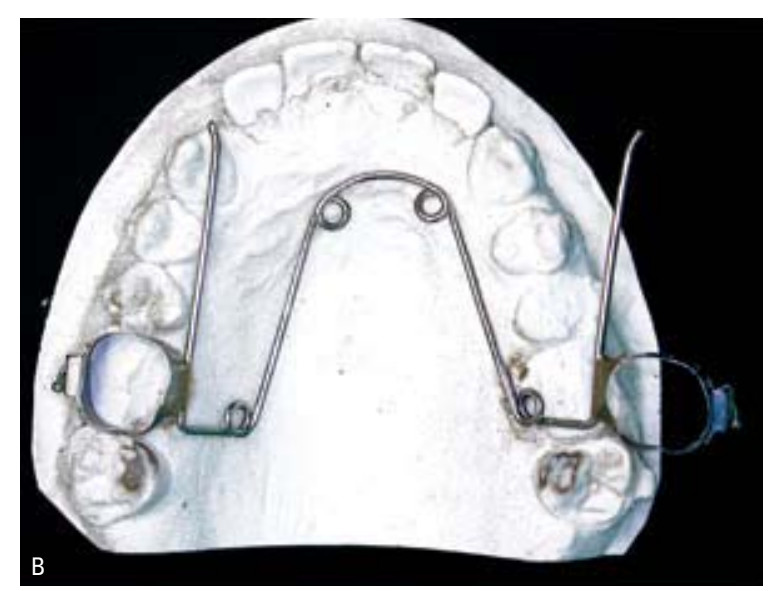


dentes mandibulares, e abrevia significantemente o tempo de nivelamento e alinhamento dentário. Ele também é muito eficiente na rotação e distalização dos molares superiores, promovendo o bloqueio dos molares superiores, o que é desejado no tratamento das más oclusões da Classe II de Angle. Assim, ele restabelece a profundidade de arco adequada, viabilizando espaços para todos os dentes do arco superior.

Agradeço ao meu amigo e assistente Rui David Paro Cambaúva pela riqueza dos seus desenhos, que tornaram mais didática a apresentação deste traba1ho. Muito obrigado meu irmão.

Enviado em: Fevereiro de 2004 Revisado e aceito: Maio de 2005

\section{The Quad-helix appliance and their variations \\ Abstract \\ The aim of this present article was to show the efficiency of several drawings of Ricketts Quad-helix appliance in the correction of dentoalveolar disharmonies. Due its varied forms, as well as its activation, the Quad-helix became a useful accessory not only in overcorrecting the transversal discrepancy and sagittal, but also in treating Angle Class II Division 1 malocclusions, mainly when molar rotation is a necessary part of the treatment. It is also relevant its effect in the treatment of anterior open-bites. It gives support in the treatment of environmental factors that contribute to exacerbate the development of malocclusions. In relation to dental arch alignment, the Quad-helix appliance abbreviate this treatment phase in 4 to 5 months, what would take, otherwise, much more time and at least a great series of changes of arches in conventional mechanics of leveling. Therefore, this work has the purpose of showing some of the possible activations, as well as some variations, of the Quad-helix appliance that contribute to get long-term stable results.}

Key words: Quad-helix. Expansion. Bioprogressive technique.

\section{REFERÊNCIAS}

1. BAPTISTA, J. M. Tração extrabucal: diagnose e terapia. São Paulo: Ed. Santos, 1985. 256 p.

2. BENCH, R. W. Apostila do curso avançado em bioprogressiva. São Carlos: [s.n.], 1999.

3. BENCH, R. W.; GUGINO, C. F.; HILGERS, J. J. Bioprogressive therapy Part 8: bioprogressive mixed dentition treatament. J Clin Orthod, St. Louis, v. 12, p. 279-298. 1978

4. BENVENGA, M. N. A colagem de "brackets", tubos e auxiliares em Ortodontia. Rev APCD, São Paulo, v. 32, n. 3. mai./jun. 1978.

5. DUARTE, M. S. As modalidades de tratamento da sobremordida profunda: extrusão ou intrusão. 1999. Dissertação (Mestrado)-Universidade Camilo Castelo Branco, Campinas, 1999.

6. DUARTE, M. S. Prescrição Pré-Ajustada - Bench. In: BATISTA, J. M. Ciência bioprogressiva. Curitiba: Editek, 1999. CD ROM.

7. DUARTE, M.S. Construíndo VTO: guia passo-a-passo. Ribeirão Preto: Livraria Dental Tota, 2002. CD-Rom.

8. DUARTE, M. S. Tratamento precoce: quando, como e porquê? In: SAKAl, E. et al. Nova visão em Ortodontia: Ortopedia Funcional dos Maxilares. São Paulo: Ed. Santos, 2004. cap. 14, p. 261-75.

9. DUARTE, M. S. Manual de cefalometria de Ricketts. Campinas, SP, [s.n], 2004. 165 p.

10. FRANK, S. W.; ENGEL, G. H. The effects of the maxillary quadhelix appliance expansion on cephalometric measurements in growing orthodontic patients. Am J Orthod Dentofacial Orthop, St. Louis, v. 81, no. 5, p. 378-389, May, 1982.

11. HAAS, A. J. Palatal expansion: just the beginning of dentofacial orthopedics. Am J Orthod Dentofacial Orthop, St. Louis, v. 57 , no. 3, p. 219-255, Mar. 1970

12. JACOBSON, A.; SADOWSKY, P. L. A. Vizualized treatment objective. J Clin Orthod, St. Louis, v. 14, p. 554-571, 1980.

13. LANGLADE, M. Otimização terapêutica da incidência trans- versal das oclusões cruzadas unilaterais posteriores. São Paulo: Ed. Santos, 1998. 384 p.

14. RICKETTS, R. M. Concepts of mechanics and biomechanics. [S. I., s. n.], 1998. 72 p. Apostila.

15. RICKETTS, R. M. Diferenças entre as técnicas com arco contínuo e a filosofia bioprogressiva. Belo Horizonte: Kelps, 1998. $170 \mathrm{p}$.

16. RICKETTS, R. M. Interview - Early Treatment, Part II. J Clin Orthod, St. Louis, v. 13, no. 2, p. 115-27, 1979.

17. RICKETTS, R. M. Interview - Early Treatment, Part III. J Clin Orthod, St. Louis, v. 13, no. 3, p. 180-99, 1979

18. RICKETTS, R. M. The wisdom of sectional mechanics. [S. I., s. n.] 1998. 61 p. Apostila.

19. RICKETTS, R. M. et. al. Orthodontic diagnosis and planning. Denver: RMDS, 1982. $269 \mathrm{p}$

20. SELLKE, T. Anotações do Curso da AAO. Dallas: [s.n.], 1998.

21. URBANIAK, J. A.; BRANTLEY, W. A.; PRUHS, R. J. et al. Effects of appliance size, arch wire diameter, and alloy composition on the in vitro force delivery of the quad-helix appliance. Am J Orthod Dentofacial Orthop, St. Louis, v. 114, no. 4, p. 311-316, Oct.1988.

22. WERTZ, R. A. Skeletal and dental changes accompanying rapid midpalatal suture opening. Am J Orthod Dentofacial Orthop, St. Louis, v. 58, no. 1, p. 41-66, July, 1970.

23. ZACHRISSON, B. U. Colagem em Ortodontia. In: GRABER T. M.; VANARSDALL, R. L. J. Ortodontia: princípios e técnicas atuais. 2. ed. Rio de Janeiro: Guanabara Koogan, 1996. p. $498-578$.

\section{Endereço de correspondência}

Mario Sergio Duarte

Rua Dr. Duarte Nunes, 275

CEP: 13.574-360 - São Carlos/ SP

E-mail: msduarte@linkway.com.br 